UNIVERSIDADE DE SÃO PAULO

INSTITUTO DE PSICOLOGIA

MARIA ESTELA ESCANHOELA AMARAL SANTOS

Os Efeitos do Luto Materno na Relação Mãe-Bebê

Versão corrigida

São Paulo

2012 


\section{MARIA ESTELA ESCANHOELA AMARAL SANTOS}

\section{Efeitos do Luto Materno na Relação Mãe-Bebê}

Dissertação apresentada ao Instituto de Psicologia da Universidade de São Paulo, como parte dos requisitos para obtenção do grau de Mestre em Psicologia Clínica.

Área de concentração: Psicologia Clínica

Orientadora: Prof ${ }^{a}$ Dra. Ivonise Fernandes da Motta

\section{São Paulo}


AUTORIZO A REPRODUÇÃO E DIVULGAÇÃO TOTAL OU PARCIAL DESTE TRABALHO, POR QUALQUER MEIO CONVENCIONAL OU ELETRÔNICO, PARA FINS DE ESTUDO E PESQUISA, DESDE QUE CITADA A FONTE.

Catalogação na publicação

Biblioteca Dante Moreira Leite

Instituto de Psicologia da Universidade de São Paulo

Santos, Maria Estela Escanhoela Amaral.

Efeitos do luto materno na relação mãe-bebê / Maria Estela Escanhoela Amaral Santos; orientadora Ivonise Fernandes da Motta. -São Paulo, 2012.

$77 \mathrm{f}$.

Dissertação (Mestrado - Programa de Pós-Graduação em Psicologia. Área de Concentração: Psicologia Clinica) - Instituto de Psicologia da Universidade de São Paulo.

1. Winnicott, Donald Woods, 1896-1971 2. Ambiente 3. Relação mãe-criança I. Título.

BF109.W55 
MARIA ESTELA ESCANHOELA AMARAL SANTOS

\title{
Efeitos do Luto Materno na Relação Mãe-Bebê
}

\begin{abstract}
Dissertação apresentada ao Instituto de Psicologia da Universidade de São Paulo, como parte dos requisitos para obtenção do grau de Mestre em Psicologia Clínica.
\end{abstract}

Aprovada em: 29/06/2012

\section{Banca Examinadora}

$\operatorname{Prof}^{\mathrm{a}} \mathrm{Dr}^{\mathrm{a}}$ Ivonise Fernandes da Motta

Instituição:

Julgamento:

Assinatura:

Prof $^{\mathrm{a}} \mathrm{Dr}^{\mathrm{a}}$ Eliana Herzberg

Instituição:

Julgamento:

Assinatura:

Prof. Dr. Claudio Bastidas Martinez

Instituição:

Julgamento:

Assinatura: 


\section{DEDICATÓRIA}

Aos meus pais, que com amor, me conceberam e se fizeram presentes até que eu adquirisse a independência necessária para me reconhecer como Eu Mesma.

À minha mãe, que no exercício de sua maternagem me ensinou a grandeza e a complexidade de ser mulher-mãe no sentido de renunciar, envolver-se, adaptar-se, iludir sem mentir, respeitar, cuidar com amor.

Ao meu marido, que me ajudou a adquirir confiança nos meus recursos e na intensidade dos nossos sentimentos de amor e responsabilidade para gerarmos uma vida e sermos capazes de dar continuidade a ela.

Em especial, ao meu filho, que me possibilitou o encontro com as minhas mais variadas formas de emoções e sutilezas inconscientes, escancarando as formas brutas e lapidadas do nosso ser, com as quais nos deparamos em cada experiência humana.

É na relação mãe-filho que podemos viver intensamente os mais nobres sentimentos, nos aprimorar e transformar a comunicação através das próprias falhas, inerentes ao humano. 


\section{AGRADECIMENTOS}

Ao casal gestante, que aceitou, se envolveu e me acolheu em seu lar para a realização deste projeto, antes mesmo de se transformarem numa família, com a chegada da primeira filha. Ao bebê-menina, cuja cumplicidade de olhares, me permitiu acompanhá-la do seu décimo quarto dia de vida até a celebração do seu primeiro aniversário e mais uns dias, como um ser único, em pleno desenvolvimento.

À Psicanálise, cujo criador, Sigmund Freud, despertou em seus seguidores a possibilidade de investigação cada vez mais profunda e precoce do desenvolvimento emocional do ser humano rumo ao amadurecimento.

A todos os colegas, professores, que em minha trajetória, através de estudos, cursos, seminários, trocas de ideias e experiências, possibilitaram-me o aperfeiçoamento e a prontidão para a experiência de observação da relação mãe-bebê na família.

À minha orientadora, $\operatorname{Prof}^{a}$ Dr $^{a}$ Ivonise Fernandes da Motta, que demonstrou interesse por minha ideia inicial ajudando-me a transformá-la em objeto de pesquisa para dissertação de mestrado. Através da sintonia de pensamentos e afeições, pudemos estabelecer uma comunicação harmoniosa e eficaz para o conteúdo aqui apresentado.

À banca examinadora, composta por pessoas a quem admiro, respeito e que disponibilizaram parte do seu tempo para enriquecer o caminho final rumo ao meu ideal. 
"Não existe isso que chamam de bebê. O que quero dizer, naturalmente, é que sempre que vemos um bebê vemos também um cuidado materno, e sem o cuidado materno não haveria bebê." (Winnicott, 2000, p. 40).

"O bebê precisava de mim e reagia a mim. Era a minha voz que ele acompanhava, o ritmo dos meus braços o mais confortável para embalá-lo, o jeito como eu o acariciava quando acordava durante a noite. Eu era essencial para ele, e também para Ernest. Eu controlava tudo.

A maternidade podia ser exaustiva, para ser sincera. Meu sono estava atrasado para sempre, e eu às vezes não tinha forças para lavar a cabeça ou comer algo mais elaborado do que pão com manteiga. Mas, quando Bumby mamava, o punho agarrando o tecido do meu robe, os olhos suaves e insondáveis presos aos meus, como se eu fosse o próprio centro do seu universo, eu não podia deixar de me fundir com ele.

A vida familiar funcionava muito bem conosco quando estávamos sozinhos, no final do dia, reconectando e sustentando um ao outro." (MacLain, 2011, p. 186-87) 


\section{RESUMO}

O enfoque desta investigação psicanalítica foi o de estudar a importância da mãe como ambiente primário facilitador ou perturbador da continuidade de ser do bebê e teve como fundamentação teórica os conceitos do pediatra e psicanalista britânico D.W.Winnicott. O método utilizado foi o "Método de Observação da Relação Mãe-Bebê na Família" criado pela psicanalista britânica Esther Bick. Dentro da abordagem winnicottiana são de grande importância todos aqueles (profissionais da saúde e familiares) que compõem o ambiente de apoio, necessário para que a mãe, a partir dos últimos meses de gestação até o final do primeiro mês de vida do seu bebê, mergulhe num estado designado pelo autor como "preocupação materna primária". Isso contribui para que se estabeleça entre ela e seu filho uma comunicação empática, envolvendo identificação de necessidades seguida de cuidados com habilidade e afetuosidade. Um bom começo compõe a base para o processo de amadurecimento saudável. O caso deste estudo, realizado em catorze meses através de observações semanais em ambiente domiciliar da família, permitiu o acompanhamento da maternagem da mãe em luto por ter perdido sua mãe, de forma inesperada, vítima de pneumonia, seis dias antes do parto. A morte da avó materna encerrou a possibilidade concreta de convivência dela entre os familiares, bem como significou a perda de holding (apoio) da gestante desde o momento do parto ao exercício da maternagem durante os primeiros meses. O ambiente primário foi afetado e os efeitos do luto materno serão demonstrados ao longo desta dissertação.

PALAVRAS-CHAVE: maternagem; ambiente; relação mãe-bebê; observação; Winnicott 


\begin{abstract}
The focus of this psychoanalytic investigation was to examine the importance of the mother as the primary facilitating or disturbing environment for the continuity of the baby's being as based on the theoretical concepts of the British pediatrician and psychoanalyst D.W.Winnicott. The "Method of Observation of the Mother-Baby Relationship in the Family", created by the British psychoanalyst Esther Bick was used. According to Winnicott, all those health professionals and family members that make up the supportive environment needed by the mother from the last months of pregnancy to the end of the first month of the baby's life are of great importance when plunged into a state designated as "primary maternal preoccupation". This helps to establish an empathic communication between the mother and her child involving identification of needs followed by skill and care with warmth. A good beginning for the baby provides the basis for a healthy maturation process. This investigation was conducted over fourteen months by weekly observations in the family home which permitted monitoring the mothering by the mother while grieving due to the unexpected death of her mother as a victim of pneumonia six days before delivery. The loss of the maternal grandmother ended the concrete possibility of her participation in the family and entailed the loss of holding for the mother prior to birth and in the practice of mothering during the first months. The primary environment was affected and the effects of this maternal grief will be described throughout this dissertation.
\end{abstract}

KEYWORDS: mothering; environment; mother-baby relationship; observation; Winnicott. 


\section{SUMÁRIO}

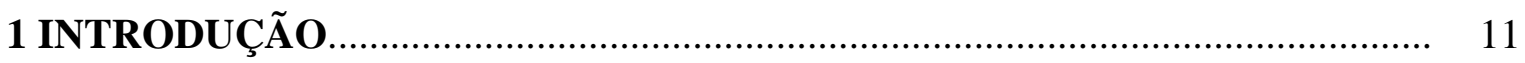

2 APRESENTAÇÃ

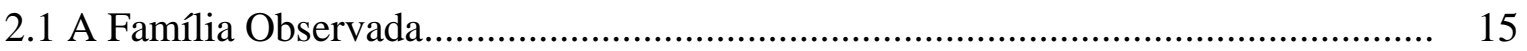

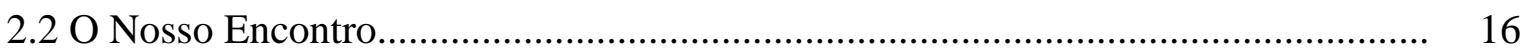

3 O AMBIENTE: OBJETIVO

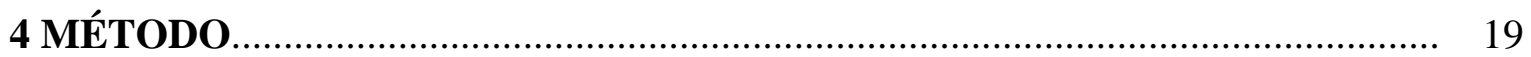

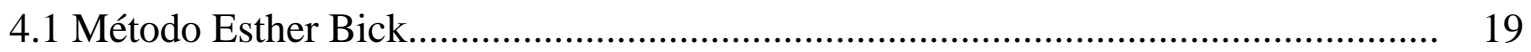

4.2 Método de Pesquisa clínico-qualitativa e a Pesquisa Psicanalítica......................... 22

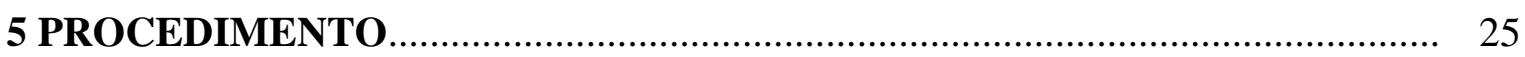

5.1 Características e realização da Observação.............................................................. 25

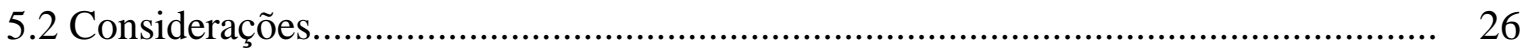

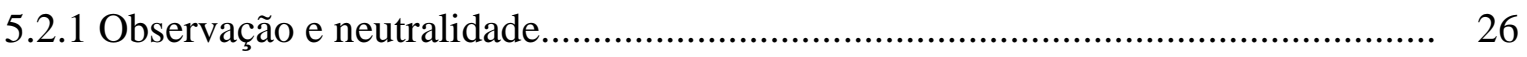

5.2.2 Apresentação do material........................................................................ 28

5.2.3 A primeira observação: entre a dor e o amor...................................................... 28

6 REFLEXÕES ACERCA DA TEORIA WINNICOTTIANA ............................... 32

6.1 Experiência da maternidade............................................................................ 33

6.2 Experiência de amamentação......................................................................... 36

6.3 Comunicação mãe-bebê............................................................................... 37

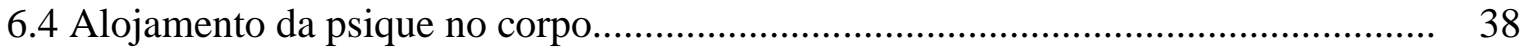

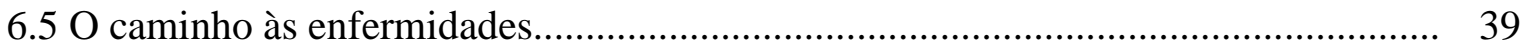

7 RESULTADOS

7.1 Ressonâncias e Reflexões................................................................................... 41 
7.2 Algumas vinhetas das Observações e Comentários............................................... 46

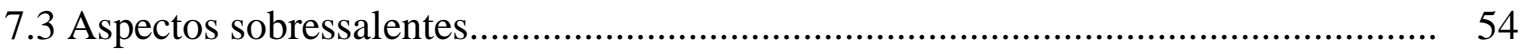

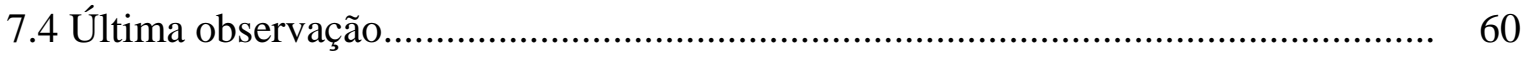

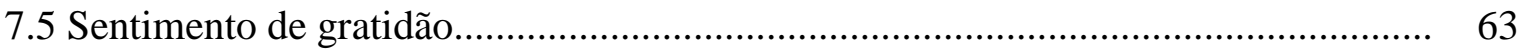

7.6 Fragmentos da visita após o período das observações segundo o método Esther

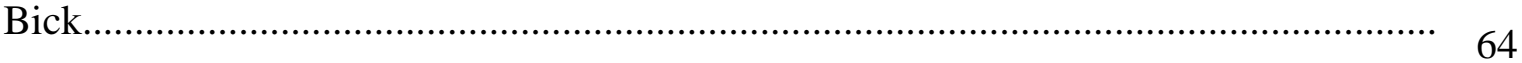

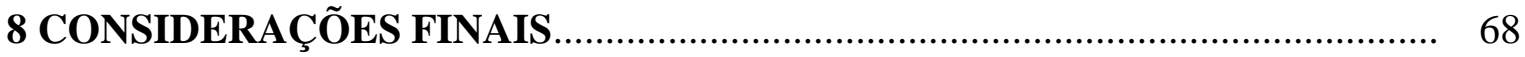

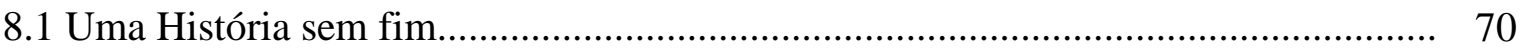

8.2 A chance de um bom começo: prevenção............................................................ 70

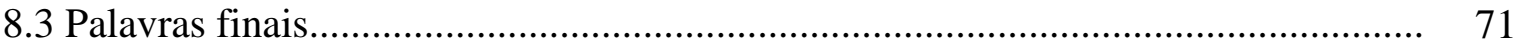

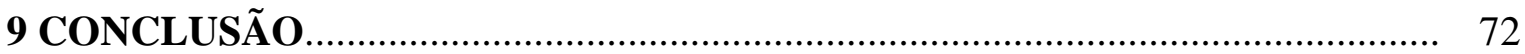

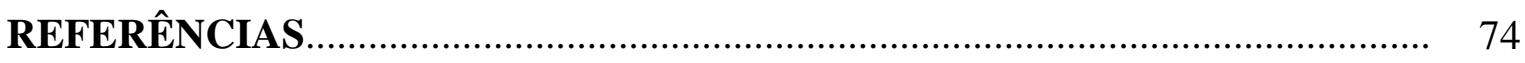

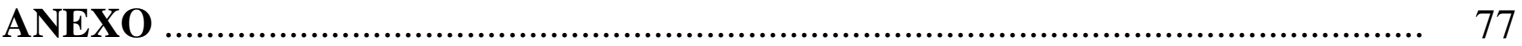




\section{INTRODUÇÃO}

"Como a experiência de perda da própria mãe seis dias antes do parto afetou a maternagem e a comunicação da dupla mãe-bebê nos primórdios da vida?"

Esta pergunta aponta para o objetivo geral desta pesquisa. O objetivo específico é demonstrar a importância do ambiente como fator de prevenção da saúde mental. Não só os laços de convivência foram encerrados como também a perda do apoio inicial previsto nos primeiros meses de maternagem da jovem que seria mãe pela primeira vez.

Numa citação de Batista Pinto (2004, p. 73), "toda a pesquisa científica implica numa teoria como base e um método como procedimento" e neste caso, tanto a conceituação teórica como o método estão fundamentados na psicanálise britânica representados por

D.W.Winnicott (teoria) e por Esther Bick (método).

O foco no ambiente refere-se ao conceito winnicottiano "ambiente primário" que inicialmente é representado pela figura materna que exerce sua tarefa com dedicação, pressentindo as necessidades e expectativas de seu bebê desde o início da vida extra-uterina, além de protegê-lo e permitir que ele viva. Não sendo suficientemente boa, não identificada com o seu bebê, a mãe como ambiente primário facilitador da continuidade de ser, permitirá a sobrevivência do recém-nascido sob a forma de reação às exigências do meio, sendo que a espontaneidade deixa de ser sobressalente nas experiências desde o início da vida.

O viver falso poderá se manifestar, entre outros, através de sintomas como irritabilidade e distúrbios alimentares. Por seu lado, a mãe deverá receber o apoio do marido, da mãe dela e de outras pessoas que a sustentem para envolver-se completamente à tarefa de ser dois em um com seu bebê.

As ideias e a prática clínica do pediatra e psicanalista D.W. Winnicott baseiam-se na observação, na experiência humana e esta foi uma das principais razões para a escolha do autor e de sua obra como base teórica à minha investigação. As conceituações teóricas se estenderão por todo o trabalho e não aparecerão formalizadas num único capítulo.

Foram realizadas cinquenta observações domiciliares a partir do décimo quarto dia do nascimento do bebê-menina até a criança completar um ano, dois meses e vinte e seis dias. As observações seguiram o máximo de passividade e neutralidade possível, na tentativa de se evitar qualquer tipo de intervenção por iniciativa da observadora, conforme proposta do 
Método. Foram registrados, após cada visita, fatos, percepções e impressões com o máximo de detalhes lembrados durante os sessenta minutos permanecidos na residência da família.

Como a observadora estimulou-se desde o início em transformar o caso em projeto de pesquisa, os pais foram informados e solicitados a manifestar-se favoravelmente ou não. Ambos aceitaram e colocaram-se à disposição para o desenvolvimento do projeto.

A revisão da literatura nos mostrou que não há nenhum trabalho específico ao título. A busca se deu através de obras, artigos, periódicos, teses, nacionais e internacionais. As consultas basearam-se nos seguintes programas: DEDALUS, PsyInfo, LILACS, INDEXPSI, Web of Science.

Nova observação foi realizada no domicílio da família no mês em que a criança completou um ano e nove meses (Abril/2012) com o objetivo de averiguação e acompanhamento do desenvolvimento da menina considerando a ampliação do ambiente que a circunda. Na ocasião, o diálogo semidirigido com os pais (ora espontâneo, ora estimulado através de perguntas pela pesquisadora) enriqueceram o estudo e a direção dos resultados.

Após conclusão da prática de observação segundo o Método Esther Bick , a família por mim observada poderá se beneficiar através do acompanhamento longitudinal do caso seguido de intervenções e apoio, sempre que houver interesse e necessidade mútuos, tanto dos pais quanto da pesquisadora.

Ficou combinado no último encontro, em abril do corrente ano, que no mínimo uma vez ao ano nos encontraremos na residência da família; além disso a pesquisadora mostrou-se disponível aos pais para atendê-los e orientá-los em circunstâncias de interesse ou necessidade.

Este estudo servirá futuramente, para novas investigações, bem como para estimular serviços de saúde voltados à orientação, prevenção e intervenção visando o cuidado do ambiente para um bom começo do processo de amadurecimento e saúde individual e familiar.

Esta pesquisa foi aprovada pelo Comitê de Ética da Universidade Paulista - UNIP. (Anexo I). 


\section{APRESENTAÇÃO}

Meu interesse pelo estudo envolvendo a importância do ambiente na constituição do ser nos primórdios da vida, incluindo o projeto de um filho na vida do casal, foi se tornando cada vez mais intenso ao tornar-me mãe e à medida que fui descobrindo novos caminhos de investigação em psicanálise - estudos do psiquismo pré, peri e pós natal - por acreditar que as bases da saúde geral de um ser humano encontram-se muito antes de ele se dar por "gente".

Quando me deparo com as palavras de Winnicott "não existe um bebê", existe a mãe segurando o bebê, o segurar, além do sentido literal, refere-se a cuidar, apoiar, reunir, sustentar, estar atento, e por que não, servir como ego auxiliar de um ser indefeso, impossibilitado de qualquer tipo de recurso próprio para continuar a ser sem a presença da mãe ou de alguém que cumpra a função materna nos primórdios da vida.

Este psicanalista e investigador nos fala do potencial herdado que todo ser humano possui em direção à continuidade aos rudimentos de ser com o qual o indivíduo nasce e que, por mais forte que seja, não sobreviverá salvo sob condições favoráveis do ambiente. Por ora, é suficiente dizer que o adjetivo favorável refere-se ao manuseio com preocupação (manusear com cuidado) e dedicação da mãe em relação ao filho recém-nascido.

A ideia de ser mãe sempre me assustou e hoje tenho mais clareza sobre o controle e adiamento por dez anos de um projeto que, para muitas mulheres, encontra-se aderido ao casamento - ter um filho. Dentre as razões, a preocupação em querer ser a melhor mãe para o meu filho, sentir o peso de uma vida "gritando" em meus braços e não saber o que fazer, além de imaginar a falta de apoio diante de uma situação desconhecida e apavorante, me levaram a estabelecer mecanismos de defesa tão consistentes que foram descortinados durante o meu processo de análise, com a experiência da maternidade e através do contato com a obra de D.W.Winnicott, cujas ideias compartilho.

Descobrir-me capaz de ser mãe sem medo de falhar e falhando, algo previsível e necessário passado o estágio de dependência absoluta para o favorecimento do processo de amadurecimento, fui ampliando meu universo de contatos e aprendizado com crianças, interessando-me cada vez mais pelos mistérios que circundam os primórdios da vida.

Minhas escolhas pessoais passaram a priorizar o ambiente em condições facilitadoras que envolvessem o curso saudável de amadurecimento do meu filho, visando viver cada idade (etapa) com suas peculiaridades e previsibilidade, mesmo diante das adversidades. 
Caminhando, acumulando experiências de vida, revivendo outras como paciente em análise, sob a chance de modificá-las, fui sendo capaz de destruir padrões indesejados, integrar e dissociar várias vezes sem perder o eixo do meu Eu e tomar consciência de que havendo confiança no ambiente sempre haverá esperança de continuidade.

Profissionalmente, passei a me sentir mais segura no atendimento infantil e a me interessar com intensidade e curiosidade pelo estudo e investigação da psicanálise envolvendo o indivíduo desde o momento em que se tornou vida pulsante no útero materno.

E assim fui me arriscando a atender crianças, a ser uma mãe possível e me deparar com o estudo do psiquismo em seus primórdios de vida, antes mesmo do nascimento.

O primeiro contato se deu através do Núcleo Psicanalítico do Espírito Santo (NUPES), vinculado à Sociedade Brasileira de Psicanálise do Rio de Janeiro (SBPRJ). Após um evento organizado pelo Núcleo, do qual sou membro fundador, tivemos o privilégio de contar com profissionais em destaque no assunto. Tratava-se de um curso de extensão em psicanálise e tinha como tema central "do feto à criança".

Nosso grupo de estudo, uma das atividades do Núcleo, passou a se interessar pelas explorações acerca do psiquismo pré e pós -natal, ao ponto de se criar o primeiro grupo de Observação de Bebês de Vitória. Éramos cinco e apenas uma realizava as visitas seguindo o Método de Esther Bick. Acompanhamos indiretamente o caso até que o bebê completou um ano e o grupo mudou o foco para atender às necessidades e expectativas de outros integrantes que foram associando-se ao NUPES.

Quanto a mim, foi um período preparatório para tomar conhecimento dessa forma de pesquisa em psicanálise e esperar pela oportunidade de realização na função de observadora da relação mãe-bebê na família. De volta a São Paulo, após um Encontro ocorrido na Unimed Sorocaba, iniciei o curso "Observação da Relação Mãe-Bebê na Família”, promovido pela Associação Pró-reintegração da Criança com duração de um ano, sob coordenação de uma psicanalista da Sociedade Brasileira de Psicanálise de São Paulo. Nessa oportunidade foi possível conciliar teoria e prática.

Olhar atentamente, ouvir, sentir a dupla mãe-bebê, conter as angústias e ansiedades, poder acompanhar o crescimento, as explorações, as habilidades, as limitações de ambas (mãe e filha) e as minhas, enquanto observadora, me ajudou a respeitar cada vez mais e mais cedo o ser humano. Estou certa de que somos movidos por relações de troca, somos relativamente dependentes e carentes do olhar do outro, da atenção do outro, da reciprocidade. 
O exercício do Método de Observação segundo a psicanalista britânica Esther Bick, me ajudou a estar mais próxima e atenta aos meus pacientes, sinto-me mais concentrada no aqui e agora da relação, certa de que, muitas vezes, aquele ser humano ali comigo apresentase em estado tal qual um bebê - desamparado e prestes a desaparecer se não for reunido e contido em suas partes numa segunda chance, ou seja, na relação analista-paciente; a primeira chance pertence à relação com o ambiente-primário: a mãe.

\subsection{A FAMÍLIA OBSERVADA}

Vanda, e Edson, que serão assim chamados, fantasiosamente em nome da ética, namoravam há aproximadamente seis anos e passaram a morar juntos no oitavo mês de gestação. Antes disso, ela morava com a mãe e os 10 irmãos e ele, também, com a mãe e os 4 irmãos. O pai dela é falecido e os pais dele são separados.

O casal observado vivia numa casa simples, bem equipada, com dois dormitórios, sala, cozinha e banheiro, num bairro de periferia de uma cidade do interior de São Paulo. A casa foi cedida a eles pela família de Edson para iniciarem a vida conjugal e familiar, a partir do oitavo mês de gravidez. Fui informada pela mãe, na visita subsequente ao período de observações, em abril do corrente ano, que a primeira conversa que tivemos os três juntos, ela, o marido e eu, na residência deles para apresentação do projeto em questão, coincidiu com a inauguração do novo lar do casal. Ambos trabalhavam e a gestante estava no último semestre de graduação de um curso na área de Ciências Humanas. O marido trabalhava por turno (das 22 às 06hs) e logo após o nascimento da filha (Sara, codinome escolhido por mim), sofreu uma intervenção cirúrgica nos joelhos e ficou impossibilitado de andar por dois meses. Ele já havia passado por duas cirurgias anteriores, sem sucesso, no joelho direito e a última envolveu ambos os joelhos; a lesão foi consequência de um confronto num jogo de futebol.

Durante o período de observação o pai esteve em recuperação domiciliar, depois através de sessões de fisioterapia tendo retornado ao trabalho pouco antes do encerramento das visitas-observação. As irmãs de Vanda se revezavam no apoio inicial aos três.

A esposa, que já havia perdido a mãe, pouco pode contar com o apoio real do esposo nos cuidados com a recém-nascida. Durante o período de observação o pai esteve em recuperação domiciliar, depois através de sessões de fisioterapia tendo retornado ao trabalho 
pouco antes do encerramento das visitas-observação. As irmãs de Vanda se revezavam no apoio inicial aos três.

\subsection{O NOSSO ENCONTRO}

Aconteceu rápido o elo entre mim e o casal gestante. A busca pelo casal foi intermediada por uma pessoa do círculo profissional da observadora que, após fornecer as referências, saiu de cena.

Em Maio de 2009 estabelecemos o primeiro contato por telefone e após uma primeira tentativa frustrada, desmarcada por eles, nos encontramos no dia dois de junho de 2009 na casa deles.

No oitavo mês de gestação a futura mamãe estava bem, contava com sua mãe para acompanhá-la à maternidade e auxiliá-la no início, após o nascimento de Sara (nome fictício). O futuro pai estava prestes a fazer uma cirurgia de joelho e provavelmente estaria em repouso. Tive a informação de que havia se machucado jogando futebol e rompido os ligamentos e que seria uma cirurgia rápida e de breve recuperação, por ser a segunda.

No final da conversa ficou estabelecido que Edson me ligaria para que a primeira visita ocorresse no Hospital Samaritano, na cidade do interior de São Paulo, Maternidade escolhida por eles para o parto, até então previsto para o dia catorze de julho.

No dia dezoito de julho, o pai ligou no meu celular para dar a notícia do nascimento de Sara que tinha ocorrido há nove dias atrás (09/7/2009). Disse que tinha sido uma correria, que mãe e filha estavam bem; no momento estava me convidando a iniciar as observações de acordo com a minha disponibilidade. 


\section{O AMBIENTE PRIMÁRIO (MÃE) : OBJETIVO DA PESQUISA}

Partindo do princípio de que no início o bebê não é uma unidade, a não ser reunido e amparado no colo da mãe, só haverá continuidade desse potencial de ser se considerarmos esse conjunto (mãe e bebê) como ambiente inicial, frutífero ou não ao processo de crescimento. É a partir do aconchego do colo, da sensação de ser adequadamente segurado (as partes do corpo reunidas, integradas) e atendido em suas necessidades básicas pela mãe em seu estado de total envolvimento e empatia com seu recém-nascido absolutamente dependente, que as experiências vão sendo armazenadas pelo bebê.

No livro "Os bebês e suas mães" (1999, p. 7), Winnicott diz que "segurança significa simplesmente ser adequadamente seguro no colo. Tanto em nível físico como em níveis mais sutis, a mãe ou o ambiente conservam a criança como que unida a si mesma”.

Desse modo, quando o ambiente primário (mãe) é facilitador vai se estabelecendo um padrão de comunicação, através da amamentação, dos cuidados maternos aplicados com dedicação e que resultará no caminho às posteriores etapas do amadurecimento humano - da incipiência à constituição do eu-mesmo.

A capacidade que a mãe possui de ir ao encontro às necessidades do filho servindo-lhe como ambiente de sustentação para um bom começo, não depende apenas das experiências registradas do bebê que ela foi e que tipo de cuidados recebeu; também pode ter ajudado a cuidar de um irmãozinho ou então, experienciado a maternagem através das brincadeiras infantis.

Este ambiente inicial (mãe) que sustenta o bebê deve ser amparado, pelo médico, enfermeiros e ampliado pelo ambiente familiar composto pelo pai, pelos avós, pelos tios, após saída da Maternidade.

As bases para o desenvolvimento do bebê no contexto da confiança no ambiente estão localizadas na maneira como é segurado e manipulado, nos primeiros meses de vida que nortearão o crescimento rumo à crença no meio ambiente, introjetada a partir da experiência de confiabilidade humana que significa, falível, não perfeita.

Por ser humana, é previsível que a mãe falhe, mas o que difere a mãe amorosa daquela que aplica os cuidados com seu bebê mecanicamente, é a busca se soluções imediatas; o bebê sente-se seguro e amado, há alguém em estado de preocupação. 
O oposto a isto seria a não preocupação em superar as falhas, impossibilitando a comunicação que se inicia através de reciprocidade na experiência física. Como exemplo podemos pensar num bebê que é carregado sem sustentação da cabeça ou que é embalado sem a preocupação de promover tranquilidade.

Winnicott (1999, p.88) aponta que não há necessidade de ensinar a um bebê que as coisas correm mal. Se isto acontece e não são logo corrigidas o bebê será afetado para sempre, seu desenvolvimento será deturpado e a comunicação estará em colapso.

Acreditando que as bases da saúde residem no estabelecimento de um ambiente primário facilitador, representado pela mãe nos primórdios da vida, estabeleço o ambiente primário (mãe) como objetivo de investigação da minha pesquisa e os efeitos do luto materno sobre as comunicações preliminares (primeiros meses) entre a mãe e seu bebê. 


\section{MÉTODO}

\subsection{O MÉTODO ESTHER BICK}

O método utilizado foi o Método de Observação de Bebês criado por Esther Bick, psicanalista britânica. Desde 1948, introduziu e passou a praticar esse método na Clínica Tavistock em Londres, como parte do curso de Psicoterapeuta de Crianças e hoje é um dos requisitos fundamentais para a formação de psicanalistas junto a IPA (Internacional Psychoanalytic Association).

É um método de observação baseado na metodologia psicanalítica que recomenda: passividade absoluta ater-se ao máximo de detalhes, procurar não usar recursos que possam influenciar na atenção e na concentração do contexto em que se passa a interação, seja durante a amamentação, durante o banho ou a situação que estiver presente no momento da observação.

O método de Esther Bick propõe que o observador tenha formação psicanalítica e encontre uma família comum, sem sinais de patologia e que seja intermediado por alguém, fora do contexto familiar ou social do observador, para que se estabeleça uma relação prévia de confiança entre este e os pais, os quais podem se recusar a participar da experiência de observação a qualquer momento. Havendo acordo, o primeiro contato deve ser realizado no final da gestação e a primeira observação logo após o nascimento, se possível, ainda na maternidade. E assim ocorrer, semanalmente, por uma hora, durante um ou dois anos.

As visitas-observações devem ocorrer semanalmente durante uma hora na residência da família, ou onde quer que mãe e bebê se encontrem. A família não pode ser do convívio social e muito menos possuir laços de parentesco com o observador. Durante, no mínimo um ano, a partir do nascimento do bebê, de preferência em dia e horário fixos, previamente estabelecidos entre a mãe e o observador, passa-se a constituição de um padrão tal qual um contrato estabelecido entre terapeuta e paciente.

Não se trata de uma visita social e a regra fundamental é a não interferência do observador, tal como fazer perguntas, comentários, aconselhar; por outro lado, não impor um silêncio absoluto às questões eventuais da mãe ou de outro adulto presente na hora- 
observação. Ele poderá responder de modo que não altere a situação, no sentido de aconselhar ou dar sua própria opinião.

Perez-Sanches (1983, p. 13-14), diz que:

É necessário que o observador sinta-se suficientemente incluído no seio da família, como que para experimentar o impacto emocional, sem se sentir, porém, comprometido a desempenhar os papéis que lhe são atribuídos, por exemplo: dar conselhos, demonstrar sua aprovação ou desaprovação, pode aceitar, sem intervir, o sofrimento de ver a mãe que não executa corretamente a sua função. Isso não exclui a possibilidade de se mostrar útil em determinadas ocasiões, seja tomando o bebê nos braços ou levando um presente às crianças, de quando em quando. Em outras palavras, deve ser um observador participante privilegiado e, portanto, agradecido. [...] Tem que encontrar uma posição através da qual possa realizar sua incumbência, introduzindo a menor distorção possível no meio. Isto é, tem que se colocar no fundo, não mostrar grande entusiasmo e não chamar atenção sobre si mesmo. O melhor é não perguntar, apenas esperar; não tomar nenhuma iniciativa porque, fazendo-o, está assumindo um papel.

Aqui podemos refletir sobre a impossibilidade de se criar um clima neutro, livre de sentimentos transferenciais e contratransferenciais, posto que numa situação de observação como a proposta por este método, por mais distante e passivo, a figura do observador presente no ambiente por si só altera o caráter espontâneo das reações e relações entre as pessoas que estão sendo observadas.

Maria Thereza de Barros França nos mostra que:

Sem interpretar, tranquilizar, ou procurar corresponder a expectativas, a simples presença do observador, oferecendo a sua capacidade de contenção, pode ser usufruída em benefício do par e até mesmo da família que se disponha a contribuir para esta experiência. (Jornal de Psicanálise, São Paulo, 25, [48], p. 96, 1992).

A autora do método não recomenda que se façam anotações durante a visita, mas considera fundamental que o observador registre posteriormente as condutas, as ocorrências e o clima emocional observado, que só poderá ser proveniente de sua própria experiência emocional, portanto isento de neutralidade. Devem-se registrar gestos, movimentos, comportamentos, acontecimentos de cada membro da família presente na situação de observação, mesmo que não considere importante ou que sejam repetitivas.

Os relatórios são apresentados a um grupo de trabalho, onde há um coordenador experiente e outros observadores que discutirão em forma de seminário os dados colhidos, bem como o impacto emocional sobre o observador. 
Não só como avaliação do desenvolvimento emocional na primeira infância, o Método de Esther Bick aplica-se como fator preventivo de distúrbios emocionais; em especial, quando o observador capta situações do ambiente, da comunicação entre mãe e filho, poderá funcionar como intervenção ao ser diagnosticado um quadro de invariâncias patológicas no desenvolvimento do bebê. Quando isso ocorre pode-se suspender a observação e iniciar o trabalho de intervenção psicanalítica para a retomada do crescimento.

A prática da Observação tem vinculação direta com a psicanálise, cujo postulado se resume em: a partir do material passível de ser visto e ouvido, trata-se de retirar o conteúdo latente, inconsciente, cuja validação e demonstração fazem sentido apenas no campo teórico do pensamento psicanalítico. O material inconsciente manifesta-se na transferência e na contratransferência de qualquer tipo de relação humana, embora nesta circunstância, em setting natural e não de consultório, seja unilateralmente interpretado posteriormente por ocasião do seminário com os demais colegas e coordenador do Observador.

Serge Lebovici aponta que no Método de Observação de Bebês criado por Esther Bick não há interpretação. Constitui-se como método que possibilita "o conhecimento das crianças pelo pensamento psicanalítico". Acrescenta: "tudo o que nos vem da infância é essencial para a teoria psicanalítica, mas essa reflexão só tem valor na medida em que nos leva a pensar, e o que ela fornece como alimento à nossa estimulação teórica dependerá sempre do enriquecimento daquele que se dedicou ao seu estudo". (JORNAL DE PSICANÁLISE, 1992, p. 132).

Esther Bick recomenda a atitude de "Tabula Rasa" durante a sessão de observação: procurar livrar-se dos pressupostos teóricos e pessoais para observar as coisas mais inesperadas - retê-las e depois pensá-las.

Korbivcher e Fontes (1992, p. 112) ao mencionar as próprias experiências como observadoras relatam:

Abstivemo-nos voluntariamente de ler qualquer bibliografia já escrita sobre o assunto. Desejamos viver a experiência em estado bruto e verificar o que dali poderia surgir como conhecimento ou descoberta.

As mesmas autoras, acrescentam, na p. 126, uma citação importante, traçando um paralelo entre a experiência de observação e a prática clínica:

Na prática clínica, os aspectos mais estruturados são representados pelas teorias psicanalíticas, que nos dão a ilusão de uma compreensão e organização das situações emocionais presentes, proporcionando uma 
tranquilização pelo apaziguamento das angústias e dos sentimentos de impotência frente ao não-ver, não-saber. O uso da "interpretação" merece assim certa atenção. Muitas vezes a função de uma interpretação está mais ligada a uma evacuação de angústias do analista do que de fato à tentativa de trazer à tona o desconhecimento do momento. Se o analista é sensível à observação do que está vivendo, tanto consigo mesmo como em relação ao paciente, conseguindo estabelecer certa divisão e manter seu norte analítico, talvez, sim, possa 'ficar' com seu cliente e não 'fugir' da situação, prendendo-se a alguma 'interpretação.' A destituição do espaço da intuição pelas teorias ou interpretações, ocasiona ilusão de um conhecimento, repetindo apenas o conhecido, impedindo o pensamento original e criativo.

Lisondo (2008, nota 3), em seu trabalho "El Despertar de La vida mental em el encuentro com el mundo externo", assinala:

A autora (1964, p. 111 - tradução nossa), valida o método na formação do pensamento científico e afirma que 'observar e pensar constituem uma unidade inseparável.' O método ensina a proceder com prudência e a confiar na validação ou refutação das hipóteses nas observações seguintes. Padrões de conduta se delineam, as invariâncias - os pais - assim como as trocas.

Na nota 10 aponta:

Não é possível falar do método Esther Bick sem o trabalho nas três etapas consecutivas: a observação do ambiente familiar; a escrita posterior do relatório; a elaboração da experiência nos seminários semanais.

Em outro momento, a autora comenta:

A observação está na origem das relações e permite compreender a conduta não-verbal do bebê, seus jogos, bem como a interpretação dos pais sobre a história da criança. (LISONDO, 2008).

\subsection{O MÉTODO DE PESQUISA CLÍNICO-QUALITATIVA E A PESQUISA PSICANALÍTICA}

A pesquisa qualitativa em psicologia clínica tem como foco de estudo o ser humano em interação e está ligada à realidade e à subjetividade do pesquisador. "Portanto, há influências diretas e indiretas, conscientes e inconscientes do pesquisador na própria ciência que produz, tendo em vista que sua produção sofre interferências de sua história e de seu funcionamento psicológico.” (BATISTA PINTO, p.77) 
O método qualitativo surgiu com as investigações nas áreas da Antropologia, Psicanálise e Cultura e para os estudiosos neste campo de pesquisa não bastam os fatos, é preciso interpretá-los para serem compreendidos.

Turato (2000, p.94) reproduz a seguinte definição de métodos qualitativos:

\begin{abstract}
A pesquisa qualitativa é multimetodológica quanto ao foco, envolvendo uma abordagem interpretativa e naturalística para seu assunto. Isto significa que os pesquisadores qualitativos estudam as coisas no seu setting natural, tentando dar sentido ou interpretar fenômenos em termos dos significados que as pessoas lhes trazem.
\end{abstract}

Como coisas o autor acima se refere a pessoas ou comunidades que acontecem - suas falas e seu comportamento.

Uma das características do método é ter o ambiente natural como local para a colheita dos dados; é nesse setting natural, seja o consultório, o local onde se presta serviços à saúde, o domicílio familiar, como é o caso da pesquisa desta dissertação, que fatos e fenômenos se apresentam e são estudados, interpretados e compreendidos.

Turato (2000, p. 101) descreve outra característica atribuída à metodologia de pesquisa qualitativa que é o pesquisador como instrumento que significa valer-se das próprias experiências pessoais para compreender os fenômenos observados e estudados.

No final do texto (p.107) o citado autor afirma que além da sociologia e da antropologia o método de pesquisa qualitativa lança mão dos conceitos psicanalíticos para fundamentar a investigação. Encerra dizendo:

E como força motriz para o cientista na pesquisa clínico-qualitativa está a sua posição existencialista, isto é, o pesquisador é movido pelas suas angústias e ansiedades pessoais para querer compreender a questão humana e, identificando-se com o outro (o sujeito alvo de seu estudo), acolhe as angústias e ansiedades deste.

A pesquisa psicanalítica descrita por Fabio Hermann (2004) ocupa-se de investigar o sentido humano nos pacientes, nos grupos e organizações compostas por indivíduos, na sociedade, bem como em suas produções culturais. Conhecida como a ciência da psique, a psicanálise tem como método investigativo a Interpretação.

Este tipo de pesquisa é muito mais que um relato clínico, pois além de descrever a história de um caso, aprofunda-se no conhecimento do psiquismo. É comum pesquisadores apoiarem-se em material clínico e desenvolver um ensaio teórico psicanalítico, ou ainda fazer 
um recorte da sociedade e da cultura, explorações técnicas, enfim, há várias maneiras de transformar o trabalho diário em pesquisa comunicável, como descrito por Hermann em seu texto "Pesquisa Psicanalítica" (2004, p. 5).

Concluindo, a clínica pode estar presente não só nas quatro paredes do consultório, mas apresentar-se de forma extensiva, como ocorreu no caso que ilustra esta dissertação de mestrado. O importante é que no habitat natural do psicanalista, o psicoterapeuta enquanto pesquisador, mantenha o rigor do método proposto na investigação. 


\section{A PESQUISA}

\subsection{CARACTERÍSTICAS DA OBSERVAÇÃO REALIZADA}

Ao iniciar as observações, no dia 23/8/2009, o bebê tinha 14 dias de vida e ao findar, em 05/10/2010, o bebê contava com um ano, dois meses e vinte e seis dias.

Até o primeiro aniversário as visitas-observação era semanais, com duração de sessenta minutos em dia e horário fixos, salvo algumas exceções; após completar um ano, passaram a ocorrer quinzenalmente. Algumas vezes, ocorreu de a observadora chegar no dia e horário pré-estabelecidos e não encontrar ninguém em casa; nesses casos, costumava aguardar em frente por dez a quinze minutos e em seguida ligar para o celular da mãe. Ora ela dizia ter se esquecido, ora que tinha se atrasado. Aqui podemos levantar algumas hipóteses e dentre elas a projeção de sentimentos agressivos da mãe em relação à observadora e por outro lado, a previsibilidade e confiança de que a observadora não a abandonaria.

Dias antes de o bebê completar cinco meses a mãe retornou ao trabalho o que nos obrigou ao encaixe na agenda respeitando as folgas semanais dela. A pesquisadora sempre procurar se adequar visando respeitar os encontros semanais previstos até que a criança completasse um ano. Vencido o período de licença-maternidade, algumas visitas foram realizadas na casa da avó materna que continuou sendo habitada pelos irmãos solteiros após a morte dela; uma das tias cuidava de Sara na ausência da mãe.

Os dados colhidos durante as observações, bem como as impressões e experiências emocionais registradas, mentalmente, no silêncio dos contatos semanais, foram escritos ou digitados oportunamente após cada visita e arquivados para reflexão futura. Esporadicamente o caso era discutido no seminário com colegas e a coordenadora do curso "Observação da Relação Mãe-Bebê na Família”.

Através de vinhetas, fragmentos de observações, a pesquisadora foi ilustrando o clima, os detalhes do que pode ver, ouvir e sentir. Os registros eram, preferencialmente, transcritos à mão, após cada visita, na tentativa de captar da memória a experiência direta e as emoções concomitantes. Como ocorre com os sonhos, nunca se chega ao conteúdo original, pois o que se passa em cada situação, muito se perde ou se distorce na transmissão, o próprio inconsciente se encarrega de fazer a seleção. 
A regra fundamental do observador era não interferir de modo algum, não fazer perguntas, não dar conselhos, mas ao mesmo tempo não permanecer em silêncio diante de eventuais questões da mãe ou do pai, desde que as palavras ou atitudes do observador não alterassem o campo da observação. Não houve qualquer tipo de retorno (devolutiva) aos pais após o término das visitas-observação, de acordo com as regra do método empregado.

No dia 07 de abril de 2012, sob acordo entre o casal e a autora deste projeto, nos encontramos na residência da família, que se mantém no mesmo endereço e nova observação pode ser realizada, assim como pai e mãe puderam ser ouvidos. $\mathrm{O}$ objetivo principal foi observar a família no final do segundo ano de vida da criança, visando os efeitos do ambiente no processo de crescimento e desenvolvimento de Sara. Permanecemos juntos durante duas horas e quinze minutos; a maior parte desta visita foi filmada e gravada, após consentimento dos pais.

\subsection{CONSIDERAÇÕES}

\subsubsection{Observação e Neutralidade}

Convenhamos, consentir que um estranho entre na intimidade de uma família, em situação de extrema vulnerabilidade, como é a chegada e os primeiros meses do primeiro filho, é um ato de coragem, bondade e confiança da família que aceita e acolhe o observador por, no mínimo um ano, em sua residência.

Por mais discreta que possa ser, a figura do observador provoca interferência no ambiente, bem como se torna fator de curiosidade e é, da mesma forma observada pelos presentes. Pude sentir isto não só por parte dos pais, como por outras pessoas da família que chegavam ou lá estavam durante a hora-observação.

Assim como pode ser sentido como invasivo, em certos momentos, o observador pode representar um apoio para a mãe, quando necessitar conversar, como ocorreu diversas vezes no caso em questão.

Para ambos os lados, eu como observadora e os pais, estávamos vivendo experiências novas - eles, com o nascimento da primeira filha, eu a primeira oportunidade de realizar a 
observação mãe-bebê na família; eu, uma estranha na vida deles, a casa deles um setting novo, a ser construído por mim.

Diante de tanta novidade, seria possível manter a neutralidade? Como não manifestar calor humano diante da beleza de um bebê no colo de sua mãe? Como esconder a ansiedade diante de situações não harmônicas da dupla? Por outro lado, é contendo-se, não se envolvendo, que se possibilita o encontro de mãe e filho através da espontaneidade e empatia.

"O analista deve ser neutro (grifo do autor) quanto aos valores religiosos, morais e sociais, isto é, não dirigir o tratamento em função de um ideal qualquer e abster-se de qualquer conselho; neutro quanto às manifestações transferenciais, o que se exprime habitualmente pela fórmula 'não entrar no jogo do paciente'; por fim, neutro quanto ao discurso do analisando.” (LAPLANCHE; PONTALIS, p. 404,1970).

Considerando que transferência e contratransferência são fenômenos que ocorrem naturalmente em qualquer vínculo interpessoal, entendo que Freud, em suas recomendações aos profissionais que exercem a psicanálise, propõe que fiquemos atentos quanto às emoções e sentimentos presentes na relação vigente no sentido de perceber, reconhecer e se manter distante o suficiente para ser capaz de investigar o que se passa, sem se deixar misturar, privilegiar ou julgar aspectos próprios ou os do paciente.

Por envolver situação de absoluto desamparo, a observação da relação mãe-bebê remete o adulto às angústias primitivas e se o observador não tem a experiência de ter sido contido pelo ambiente-mãe e posteriormente através da análise, ficará muito mais difícil perceber em si mesmo e conter os sentimentos despertados, semanalmente, com a experiência de visitas-observações.

Não só o bebê, como a mãe, o pai, podem manifestar necessidade de proteção estimulando o observador a reagir de alguma forma. Neste caso, antes de interferir impulsivamente, sempre que percebi tal manifestação por parte da mãe, em especial, procurei deixá-la à vontade para agir só respondendo a uma solicitação após tentativas de autonomia em relação a certos procedimentos ou manuseio com o bebê. Como ilustração a o que me refiro, cito uma vinheta da $1^{\mathrm{a}}$ Observação (bebê com 14 dias):

...Instantes depois a mãe retirou o bebê do seio e disse: "tá na hora do remédio, ela tomou meia-noite, 8hs e (começou a contar nos dedos) 4, isso mesmo. Olhou em direção à mesa da TV onde tinham duas caixas de medicamentos, levantou com a filha no colo, pegou as caixas, identificou-os e não estava conseguindo manejar a abertura do frasco com S. no colo. Olhou em direção ao quarto do casal, onde 
o marido se encontrava, voltou-se em minha direção e disse: "quer segurar ela um pouquinho?"Passou a bebê pra mim dizendo: "vai com a tia um pouquinho.

Pude perceber que as informações transmitidas no nosso primeiro encontro, antes do nascimento de Sara, sobre as atitudes do observador de não interferência e o máximo de passividade, tinham sido entendidas e acolhidas pela mãe. Por outro lado, pude me reconhecer capaz de evitar interferências sem me posicionar com frieza e rigidez.

\subsubsection{Apresentação do Material}

Serão apresentadas vinhetas de observações acompanhadas de comentários e reflexões. Em seguida, descreverei alguns conceitos teóricos pertinentes ao contexto como proposta de integração da prática com a teoria que a fundamenta.

A apresentação de ideias e aplicações merece atenção e respeito mediante conceitos teóricos que as sustentem. Defendê-las significa acreditar, tendo como ponto de partida a identificação dos postulados com aspectos subjetivos, estritamente pessoais.

Refiro-me à relação que existe entre cada indivíduo e as escolhas de autores, pensadores, que vão de encontro às necessidades de busca de algo que complete, dê sentido e continuidade, assim como se processa o encontro da dupla mãe-bebê toda vez que se busca o seio e lá está ele no momento.

Ideias ganham significado e consistência quando embasadas em fatos, fenômenos articulados com teorias coerentes. Assim foi minha trajetória até o contato com a obra psicanalítica de D.W.Winnicott.

\subsubsection{A primeira observação: entre a dor e o amor}

Iniciei a primeira de cinquenta observações no dia 23/7/2009, aos catorze dias de vida de Sara. Nesta primeira visita, por várias vezes fui tomada por pensamentos-flash: pensamentos não elaborados que irrompem na mente do observador (KORBIVCHER; 
FONTES, 1992, p. 114). Um deles me dava a "certeza de que o bebê ia cair" quando a mãe deixava Sara solta, deitada sobre suas pernas enquanto ajeitava o seio oposto para continuar a amamentação. Essa vivência de ruptura da continuidade ressoava em mim e várias vezes precisei conter meu impulso de amparar esse bebê.

...Ajeitou a filha no colo em posição deitada - o bebê ficou totalmente solto enquanto a mãe retirava o seio direito para amamentar.

Tirou a filha do seio direito e deixou-a deitada em suas pernas, enquanto arrumava o sutiã. O bebê permaneceu alguns segundos solto e isso me angustiou - contive o impulso de ampará-la. (Primeira Observação - bebê com 14 dias)

Para Winnicott a sensação de "cair pra sempre" é uma das agonias impensáveis que interrompem a continuidade de ser devido a um padrão de falhas repetidas do ambiente primário (mãe).

Outro momento de angústia para a observadora na primeira visita: ao invés de colocar a filha em pé para arrotar após ser alimentada, a mãe a balançava. O bebê parecia protestar através de expressões faciais e resmungos, até Vanda posicioná-la verticalmente.

\footnotetext{
A mãe disse:

"Vamos arrotar? Ela demora para arrotar".

Mais um momento de tensão para mim, pois ao invés de colocá-la em pé para facilitar o arroto, a mãe balançava o bebê como se estivesse embalando-o para dormir.

Sara fazia caretas, resmungava até que a mãe colocou-a de pé, de frente para mim e disse: "olha a tia, é tia nova, essa você não conhece”. (Primeira Observação)

"Você acredita que ela pegou um resfriadinho? Tá com tosse, percebi que tinha secreção e segunda levamos ela ao pediatra - tá tomando remédios, um para a tosse e outro para descongestionar." (Primeira Observação).
}

Chamou-me a atenção o fato de saber que Sara, tão novinha, estava resfriada fazendo uso de medicamentos. Isso foi marcante durante todo o processo de observação - o bebê apresentava-se, ocasionalmente, doente.

Por quase todo o intervalo da Primeira Observação, percebi um bebê que chorava, resmungava, sugava, requisitava, até silenciar-se no colo da mãe. Nesse momento tive a forte impressão de que o bebê passou a funcionar como ambiente de holding (apoio) quando a mãe começou a me contar, com emoção, sobre os acontecimentos que desencadearam a internação 
e morte inesperada da mãe dela, cuja causa foi uma gripe que se complicou e evoluiu a óbito. A avó iria acompanhar a filha na Maternidade e dar-lhe apoio domiciliar no início da maternagem de Vanda.

Antes que eu me mencionasse o término do horário ela me disse: "deixa eu contar uma coisa que aconteceu, nem deu para contar antes. Lembra que eu falei pra você que minha mãe ia me ajudar no começo com o nenê?"

Obs.: "Lembro."

Mãe: "Em junho, depois do dia 20, você veio aqui acho que foi no começo do mês, eu (gestante) tava no oitavo mês, não foi?"

Obs.: "Isso, você tinha entrado no $8^{\circ}$ mês."

Mãe: No final do mês minha mãe ficou doente, teve uma crise respiratória, ela já estava doente antes mas nós achamos que não era nada grave.

Mãe: $O$ E. levou ela no hospital, o médico atendeu, falou que era uma crise respiratória e mandou pra casa. Ela piorou e nós levamos ela de volta para o hospital no domingo, eu fiquei lá com ela, ela não podia falar, tava com aparelho, mas fez sinal que não estava bem. Chamei a enfermeira e falei que minha mãe não estava bem, que precisava ir pra UTI. Ela chamou o médico e minha mãe ficou na UTI até quartafeira e daí (começou a chorar), a gente não sabia que era tão grave.

Obs.: "Não me diga que ela..."

Fez sinal afirmativo com a cabeça e disse: "ela morreu dia 03 ".

O bebê permanecia quieto no colo da mãe enquanto esta me contava e já chorava bastante.

Mãe: "Tão nova, 56 anos, o médico disse que o coração dela enfraqueceu com a pneumonia."

Obs.: "Eu sinto muito, muito mesmo pelo que aconteceu. A vida prepara muitas surpresas, trouxe a vocês uma menininha linda $e$ levou sua mãe."

Mãe: "É mesmo", disse M.

Obs.: "Ela vai ajudar você a superar essa dor."

Mãe: "Já tá ajudando, né filha. Agora eu não consigo ir muito na casa da minha mãe, onde ficaram meus irmãos, tudo lembra ela. Dos onze oito moram lá."

O bebê antecipou sua chegada trazendo vida ao espaço da perda deixado pela avó, mas pode ter causado na mãe intensa angústia de morte observada pelo excesso de medicamentos ministrados ao longo do primeiro ano de vida, além de várias vezes ter acordado a filha para alimentá-la e ainda, pelas comparações em relação ao desenvolvimento do seu bebê e os outros. (SANTOS, 2010).

Ao tomar conhecimento dos fatos, pude entender algumas das manifestações emocionais surgidas naquele primeiro encontro da Observação. 
Meu objeto de interesse (relação mãe-bebê no início da vida) começou a evidenciar que a comunicação na dupla poderia ser afetada de alguma forma, após a perda da avó materna, supostamente figura de holding da mãe do bebê.

O que pudemos observar desde o início das observações desta relação é que amor e dor se revezavam através de expressões de ansiedade, angústia, silêncio, negligência, medo, agressividade, fragilidade, alegria, vitalidade, compreensão, cuidado, preocupação. 


\section{REFLEXÕES ACERCA DA TEORIA WINNICOTTIANA}

Por ter sido pediatra, antes de se tornar psicanalista, o autor equipara bebês e psicóticos no processo de amadurecimento, rumo à constituição do si-mesmo que ele denomina Self. A boa maternagem do ambiente primário promoverá a passagem do bebê da imaturidade à maturidade ao longo de um processo.

O ambiente, é descrito e sustentado teoricamente por Winnicott como o principal aspecto no processo do amadurecimento; primeiro, representado pela mãe, em seguida pelo pai, seguido pelos demais familiares, ampliando-se pela escola e comunidade, em geral. $\mathrm{O}$ ambiente primário se adapta ao bebê e a partir daí, vai se expandindo e sempre apontado pelo autor como fator facilitador para o caminho do desenvolvimento.

Conforme a descrição do parágrafo anterior, o bebê, movido por uma tensão instintual, que nem imagina ser parte dele mesmo, faz um movimento qualquer em direção a algo e encontra o seio ou a mamadeira; a mãe, atenta, aproxima o seio ou a mamadeira para que seja encontrado.

Está criado o primeiro gesto espontâneo, criativo e a ilusão de que o bebê criou algo em resposta à sua necessidade. Como mãe e bebê formam uma só unidade, inicialmente, o bebê tem a ilusão de que é ele quem cria o seio. Winnicot (1999, p. 56) nos alerta para o paradoxo de que aquilo que o bebê ria já estava ali, pois é parte da mãe e que isso só se torna possível pelo estado em que a mãe se encontra desde o final da gestação - de estar presente e atenta, no momento e no lugar certo, às necessidades do filho e o permite descobrir o mundo de forma criativa.

Assim como não há um bebê sem sua mãe, não há mãe se não houver um bebê. Toda mulher já experimentou a maternidade recebendo maternagem quando era bebê, brincando de boneca, mas é tornando-se grávida que experimentará, de fato, a importância de um ambiente de holding (apoio) para tornar-se o primeiro ambiente de sustentação para o filho que irá chegar. Inicialmente, são o colo e os braços da mãe que compõem o ambiente. 


\subsection{EXPERIÊNCIA DA MATERNIDADE}

Vejamos o que o autor fala sobre isto: "não se pode esperar que uma pessoa seja sempre bem-sucedida. Em geral, há alguém disponível para providenciar o que for necessário - talvez o pai da criança, uma avó ou uma tia, nos casos em que uma mãe não for capaz de fazê-lo com nenhum bebê.” (WINNICOTT, 1999, p. 74).

Um estudo antropológico da maternidade revela que "talvez o que melhor caracteriza as mulheres que são mães seja a qualidade dos cuidados (grifo do autor) dispensados aos filhos.” (KITZINGER, 1978, p. 22). Segue dizendo que o mergulho à maternidade nas primeiras semanas após o parto, caracteriza-se pelo estado mental semelhante à psicose, que capacita a mãe a estar prioritariamente atenta às necessidades do seu bebê: sua respiração, tipo de choro, manifestações de toda ordem, provenientes daquele ser em completo estado de desamparo.

Winnicott "chamou de 'preocupação materna primária"”, que embora seja um estado temporário, guarda muitos de seus elementos por todo o exercício da maternidade, numa relação de intimidade, de renúncia às suas próprias necessidades às dos filhos, em qualquer idade (KITZINGER, p. 23). Por mais falhas que tenha cometido, o predomínio deste tipo de relação mãe-bebê terá formado as bases para o desenvolvimento de um indivíduo capaz de dar e receber amor.

Ainda sobre o conceito criado por Winnicott, durante os últimos meses de gestação, a mulher entra, naturalmente, em estado de extrema sensibilidade, atenção e comunicação prioritária com seu bebê, sendo capaz de sentir o que ele sente. É um estado que se prolonga por alguns meses após o nascimento nomeado por ele como Preocupação Materna Primária; o conceito de mãe devotada comum e o de mãe suficientemente boa estão inseridos neste contexto. O termo suficientemente significa cuidar por ter sido cuidada, algo que se experimenta, não se aprende em nenhum livro; trata-se de uma experiência humana e portanto, suscetível a falhas, bem como, com capacidade de recuperação a contento.

“O ambiente facilitador é, no início, a 'mãe suficientemente boa' (DIAS, 2003, p. 133). Ser suficiente tem aqui o sentido de ser real, espontânea, praticar os cuidados com destreza e dedicação, sem a necessidade de ser perfeita, privilegiando as necessidades do bebê e não das suas próprias. 
A mulher precisa de apoio nesse período, pois a mãe é o primeiro ambiente favorável para o vir-a-ser do bebê; o marido, a mãe dela, a família e o ambiente social mais íntimo são os melhores apoios para esse breve espaço de tempo em que a dupla vive em sistema de clausura.

Ambos encontram-se vulneráveis e dependentes e por ter sido bebê, um dia, a mãe passou pelas mesmas necessidades e aquilo que foi experienciado não se perde; portanto, se tudo correu bem entre ela e sua mãe no início da vida muito servirá para adaptar-se às necessidades do filho que vive tudo pela primeira vez, em estado de absoluta dependência.

Preocupação Materna Primária é definida como uma condição organizada, comparada a um estado de retraimento ou de dissociação, ou de fuga, ou mesmo de um episódio esquizóide, no sentido de que um aspecto da personalidade fica no comando temporariamente. Há uma tendência a cair no esquecimento (ficar reprimido) após recuperarse da "doença" - termo empregado pelo autor para dizer que a mulher tem que estar saudável para desenvolver esse estado tanto quanto para livrar-se dele na medida em que o bebê vai amadurecendo e cumprindo as etapas previstas no processo de amadurecimento. (WINNICOTT, 2000, p. 401).

Essas etapas pressupõem "tarefas" previstas e distribuídas desde o estado do não-ser (solidão essencial), antes mesmo da concepção até o envelhecimento e volta ao estado inicial (não-ser) que culmina com a morte. O autor descreve estágios para cada período de vida que vão da Dependência Absoluta à Independência Relativa e esclarece que a linha do amadurecimento não é linear, movimenta-se por caminhos evolutivos e regressivos de acordo com o ambiente, propício ou desfavorável ao crescimento ${ }^{1}$.

Ao se recuperar desse estado de devoção ao bebê a mãe volta a ser mulher, esposa, profissional, bem como poderá retomar suas atividades sociais; nada garante que ela desenvolva a preocupação materna primária nas próximas gestações, levando-se em consideração que cada filho é único e as circunstâncias que envolvem a gestação, o parto e o nascimento também são imprevisíveis.

No caso deste estudo, o bebê nasceu em circunstâncias que romperam um estado tranquilo de expectativas que envolvia parto e apoio. Há fatores adversos no decorrer da vida das pessoas que modificam o percurso natural dos acontecimentos, como a morte inesperada da avó materna com quem os pais do bebê contavam como apoio.

\footnotetext{
${ }^{1}$ Para maior compreensão sobre o Processo de Amadurecimento de D.W.Winnicott ver Dias, 2003.
} 
A mãe devotada, que entra em estado de especial atenção e preocupação pouco antes do parto, conseguirá agir naturalmente e empaticamente com seu bebê se estiver livre de teorias e das pressões externas. É no manejo que irá desenvolver e empregar suas técnicas e regras que melhor se adaptem ao ritmo e necessidades do seu bebê, que ninguém melhor do que ela conhece.

A primeira e grande comunicação empática entre o bebê e sua mãe poderá ocorrer no momento do parto - quando ambos vivem simultaneamente a experiência de entregar-se para o rompimento da vida intra-uterina que está pronta para dar continuidade do lado de fora. Acredito que essa primeira experiência mútua é o primeiro sinal de confiança que se estabelece entre os dois, sustentados por um ambiente seguro e confiável - marido, mãe, médicos, enfermeiros, salvo em situações onde ocorrem complicações no parto ou pós-parto.

Não mencionarei aqui casos em que os partos não aconteceram a termo ou que possam ter sofrido complicações. No cap. XIV (Memórias do Nascimento, Trauma do Nascimento e Ansiedade - p. 254, 1949) do livro Da Pediatria à Psicanálise (2000), Winnicott descreve alguns casos interessantes sobre experiências do nascimento.

Ao deixar a maternidade e todo o apoio ali experimentado não só pelo marido, pela mãe, irmãos, enfermeiros e médicos, a jovem chega em casa carregando nos braços uma vida que depende, essencialmente, dela para continuar existindo. Inerente a isto, seu estado emocional revela pouca confiança em si própria mediante uma situação completamente nova, mesmo que tenha observado ou ajudado a cuidar de bebês anteriormente.

Passa a se dar conta de que está isolada, solitária em diversos momentos do dia e da rotina com o recém-nascido, mesmo com a presença do marido ou de qualquer outra pessoa. O apoio da mãe dela ou do marido não retira de si a responsabilidade e o grau de dependência que um filho, naquele período inicial, exige da mãe.

No caso em questão, a mãe perdeu o apoio concreto da própria mãe, após sua morte bem como o apoio do marido, que se encontrava em estado de recuperação cirúrgica do joelho. Ao voltar às atividades profissionais o pai continuou limitado e de certa forma ausente no ambiente, pois trabalhava no período noturno e dormia durante o dia.

Houve a necessidade de uma nova reestruturação desta família à realidade inesperada - a ambivalência amor e dor estava fortemente presente nesse lar. A procedência familiar de ambos, o resgate dos cuidados recebidos, as bases constitutivas de um bom começo, foram fundamentais para que o ambiente primário (mãe) se estabelecesse predominante e favoravelmente naquela situação. 


\subsection{EXPERIÊNCIA DE AMAMENTAÇÃO}

A amamentação tem seu valor altamente positivo, desde que a mãe não tenha nenhuma dificuldade pessoal para realizá-la. A mamadeira também possui a maioria dos aspectos que são importantes no momento de alimentar um bebê, excluindo-se o cheiro, o gosto e a troca sensual. Nessa experiência toda a personalidade em formação está envolvida e há bebês, cujas experiências são tão empobrecidas que se aliviam ao chorar de raiva e frustração. Já outros, alimentados com intensidade de emoções e sensações agradáveis por uma mãe que olha e encontra o olhar do bebê, sente prazer em alimentá-lo, enfim, há um compartilhar no que ambos sentem e experimentam.

[...] quando a mãe e o bebê chegam a um acordo na situação de alimentação, estão lançadas as bases de um relacionamento humano. É a partir daí que se estabelece o padrão da capacidade da criança de relacionar-se com os objetos e com o mundo. [...] O bebê é um ser humano imaturo, extremamente dependente, e também um indivíduo que está tendo e armazenando experiências. (WINNICOTT, 1999, p. 55).

No começo foi meio difícil até ela pegar o seio, eu tinha bastante leite chegava a doer porque ela não tinha força pra mamar. Agora não, ela mama bem,mama toda hora. (Primeira observação)

Há, contudo, por volta dos seis meses, aproximadamente, o aparecimento da agressividade de forma mais contundente como chutar, gritar, arranhar.

Winnicott nos lembra (1999, p. 25-26) que :

Na situação de alimentação havia, no início, uma atividade vigorosa da gengiva, um tipo de atividade que pode facilmente resultar em rachaduras no mamilo; alguns bebês aderem realmente ao seio com as gengivas e o machucam bastante. Não se pode firmar que estejam tentando ferir, porque o bebê ainda não está suficientemente desenvolvido para que a agressividade já possa significar alguma coisa. Trata-se de algo muito importante, que diz respeito à crueldade, aos impulsos e à utilização dos objetos desprotegidos. Muito rapidamente, os bebês passam a proteger o seio, e na verdade é muito raro que mordam com o objetivo de ferir, mesmo quando já possuem dentes.

O Bebê desta pesquisa não desenvolveu a dentição durante o primeiro ano de vida. Nesta fase, é importante que a mãe, ao perceber o que se passa, proteja-se sem valer-se de 
retaliação ou vingança. Sua função, aos arranhões, puxões de cabelo, gritos e chutes é a de sobreviver e o bebê, certo da sobrevivência da mãe, encontrará um novo sentido para a palavra amor e a fantasia surgirá em sua vida.

É como se o bebê agora pudesse dizer à sua mãe: 'eu a amo por ter sobrevivido à minha tentativa de destruí-la. Em meus sonhos e em minha fantasia eu a destruo sempre que penso em você, pois a amo'. É isto que objetifica a mãe, coloca-a num mundo que não é parte do bebê, e a torna útil. (WINNICOTT. 1999, p.26)

A base para o desenvolvimento saudável desta etapa consiste exatamente na sobrevivência real da pessoa atacada, bem como a não transformação desta em um ser humano vingativo e retaliador. A mãe, em primeiro lugar, depois, o pai, animais e brinquedos farão parte dessa experiência. "Os bebês não se recordam de que as pessoas os seguravam bem, no entanto, lembram-se da experiência traumatizante de não terem sido segurados de forma adequada." (WINNICOTT, 1999, p. 54).

\subsection{COMUNICAÇÃO MÃE-BEBÊ}

"A base de todas as teorias sobre o desenvolvimento da personalidade humana é a continuidade, a linha da vida, que provavelmente tem início antes do nascimento concreto do bebê. [...]" (Winnicott, 199, p.79). O potencial herdado só se manifestará mediante um ambiente primário favorável, representado pela mãe suficientemente boa.

No início, não há uma divisão entre aquilo que constitui o não-eu e o eu e nesse contexto especial dos relacionamentos iniciais, o comportamento do meio ambiente faz parte do bebê da mesma forma que o comportamento dos seus impulsos hereditários para a integração, para a autonomia e a relação com objetos, e para uma integração psicossomática satisfatória.

Algumas pessoas se surpreendem quando ouvem dizer que as tendências hereditárias de um bebê são fatores externos, mas eles são tão claramente externos à pessoa do bebê quanto o é a capacidade que a mãe tem de ser suficientemente boa, ou sua tendência a ter dificuldades no que está fazendo, por estar deprimida. (WINNICOTT, 1999, p. 80). 
Algum tipo significativo de comunicação ocorre desde o início da vida de cada indivíduo, e que, seja qual for o potencial, o desenvolvimento pode ser retardado ou deturpado a qualquer momento, e pode nunca vir a se manifestar, dependendo da continuidade das falhas que incluem as omissões do ambiente-mãe.

Não é preciso pensar nas falhas básicas (grifo do autor) de adaptação como uma forma básica de comunicação. Não precisamos ensinar um bebê que as coisas correm muito mal. Se correm mal e não são logo corrigidas (segundos, minutos, horas), o bebê será afetado para sempre, seu desenvolvimento será deturpado, e a comunicação entrará em colapso. (WINNICOT, 1999, p. 88-89).

Quando as falhas são corrigidas em tempo, quebrando um padrão que impede a continuidade de ser, o desenvolvimento prossegue e o bebê adquire um interior e um exterior e a confiabilidade do meio ambiente passa a ser um a crença.

É como se a mãe dissesse: "sou confiável porque sei do que você está precisando, quero lhe oferecer o que você busca e deseja, me preocupo." Isto é o que Winnicott chama de amor neste estágio de desenvolvimento. Este tipo de comunicação é, porém, silencioso. O bebê não ouve ou registra a comunicação, mas apenas os efeitos da confiabilidade; é algo que se registra, em algum lugar, no decorrer do desenvolvimento e no início, esses registros estão instalados no corpo.

\subsection{ALOJAMENTO DA PSIQUE NO CORPO}

Logo no início da vida, psique e soma não estão diferenciados e só o serão se tudo correr bem entre a tendência herdada à integração e o ambiente suficientemente bom. A operação psicossomática é uma realização e nem sempre é alcançada, ou mesmo que seja, poderá ser perdida e novamente conquistada - podemos dizer que esta é a dança a caminho da saúde. Essa conquista, do alojamento da psique no corpo, depende do modo como se dá o cuidado materno em relação ao manejo (handling) do corpo do bebê e de como essas partes reunidas daquele ser vivo, mole, solto, ficará reunido no colo da mãe, cujo segurar (holding) propiciará experiências sensórias de aconchego, morada e unidade.

Para a mãe, o bebê já é uma pessoa total, mesmo que nós, estudiosos do assunto, saibamos que se trata de um vir-a ser. Porém, o manuseio deverá constar de habilidade 
seguido de afetuosidade, respeito e sintonia, para que a primeira morada se constitua em experiências positivas de limites da pele, espacialização e a oportunidade de entregar-se a estados de não-integração através do descanso relaxado.

O processo de localização da psique no corpo se dá por experiências pessoais impulsos e sensações da pele, erotismo muscular, instintos (ligados à excitação, aos cuidados do corpo e à satisfação de exigências instintivas que produzem gratificação). Como exemplo, podemos citar o bebê que ao ser despido fica se movimentando espontânea e prazerosamente; em fases posteriores da vida, o prazer na prática de exercícios físicos.

Na p. 205 de "Explorações Psicanalíticas" (2007) Winnicott diz:

...o começo daquela parte do desenvolvimento do bebê, que estou chamando de personalização, ou que pode ser descrita como uma habitação da psique no soma, tem de ser encontrado na capacidade que a mãe ou a figura materna tenham de juntar o seu envolvimento emocional, que originalmente é físico e fisiológico.

Geralmente, o bebê recebe uma série de cuidados maternos repetitivos por parte da mãe que combina atenção física e psicológica; sendo harmônico este começo, dificilmente esse bebê necessitará de um fisioterapeuta no decorrer da vida, conforme nos alerta Winnicott. Ele diz: “... o fisioterapeuta executa um trabalho profissional a partir da mesma coisa que foi chamada de cuidado amoroso no manejo inicial.” (WINNICOTT, 2007, p.431).

\subsection{O CAMINHO ÀS ENFERMIDADES}

Podemos apontar a enfermidade psicossomática como uma unidade que não se constituiu, ou seja, a psique e o corpo, não são inicialmente uma unidade e só o serão, se houver um bom começo a partir do trabalho da fisioterapia da mãe, que reúne manejo do corpo do bebê com amor.

$\mathrm{O}$ intelecto e a psique dependem do funcionamento do cérebro. Tratando-se de desenvolvimento o intelecto não adoece mesmo que a psique adoeça; porém, independente de um cérebro saudável, a psique pode estar doente, perturbada por falhas no desenvolvimento. Para melhor entendimento podemos falar de uma criança com QI elevado, mas, comprometida emocionalmente, bem como é possível encontrar outra com QI abaixo do normal com desenvolvimento emocional saudável. 
Conforme o cérebro vai se desenvolvendo, vai acumulando experiências e a armazenagem de memórias relativas ao corpo, que são individuais, é responsável pela formação de um novo ser humano. Essas experiências têm início na vida intra-uterina, como já mencionado anteriormente. Podemos supor que bem antes do parto muita coisa já tenha sido experimentada pelo bebê e após o nascimento ele terá acumulado centenas de experiências pessoais.

Embora exista uma tendência inata ao crescimento, isto fica em segundo plano devido à dependência total a um ambiente voltado às necessidades presentes no início da vida. A psique está sujeita a falhas e fracassos esporádicos, cujas distorções deixarão marcas. O desenvolvimento emocional saudável interfere diretamente na saúde física e o contrário também é de grande importância para a vida de uma criança.

Na Parte IV, cap. 2, p. 137 do livro "Natureza Humana", Winnicott diz o seguinte sobre o conceito de Integração: "Em psicologia, é preciso dizer que o bebê se desmancha em pedaços a não ser que alguém o mantenha inteiro. Nesses estágios o cuidado físico é um cuidado psicológico".

Neste estágio a falha ambiental refere-se à inadequação em relação ao manuseio para tirar o bebê do berço, ou carrinho para o colo ou banho. Espera-se que ao realizar estas ações os gestos da mãe constituam a junção das partes do corpo proporcionando conforto e segurança ao bebê. Isto Winnicott conceitua como "Integração". Essa experiência, vivida repetidamente, compõe o sentimento de sanidade e o oposto, a sensação de enlouquecimento e, consequentemente, "Desintegração".

É interessante salientar que o sentimento de integração pode desaparecer sob a aquisição do sentimento de confiança; quero dizer que no colo seguro e confiável, a criança poderá entregar-se e entrar em estado de não-integração por confiar no ambiente que o mantém devidamente seguro.

Um bebê aceito, cuja mãe não se envergonhe, não se sinta culpada por algo que não tenha vindo de acordo com suas expectativas ou de acordo com o que é estabelecido nos padrões culturais e de saúde como normais, poderá desenvolver um self sadio a partir de suas experiências de aceitação e amor; refiro-me a aceitação do filho independente de ser portador de alguma deficiência física ou mental. 


\section{RESULTADOS}

\subsection{RESSONÂNCIAS E REFLEXÕES}

Embora tenha mantido a regra "ouvir com os olhos" (KHAN, 2010), o máximo possível, a observadora captou e foi tomada por emoções diversas durante o período de observação, em vários momentos. Trata-se de ressonâncias que se pretende inserir aqui como proposta de reflexão, da mesma forma que se tentará fazer um elo entre o conteúdo observado e os conceitos psicanalíticos como direção à compreensão deste caso.

Com a família observada não foi diferente. O elemento surpresa testou minhas defesas logo na primeira visita; cheguei com expectativas de um padrão pré-estabelecido e me deparei com algo impactante e imprevisível. Só no limite do tempo, prestes a esgotá-lo, a mãe sucumbiu e dividiu comigo seu sofrimento. Naquele momento, a dor passou a ser minha também e a primeira experiência de observação com um mínimo de neutralidade me levou a questionar a possibilidade de manter frieza diante de tal sofrimento e desamparo. O que vivi ali me aproximou ainda mais do humanismo de Winnicott, o que me permitiu acompanhar, compartilhar com a dupla mãe-bebê emoções intensas e impensáveis.

A vinda antecipada de Sara, seis dias antes, me levou a pensar na força inconsciente de dar vida à morte. Na desordem familiar gerada pela perda da avó materna, o nascimento daquela menina se interpôs no processo de elaboração do luto, estimulando a mãe a exercer a maternagem e garantir ao bebê a continuidade de ser.

$\mathrm{Eu}$, também, precisei de um tempo interno para me recompor e continuar minha função de observadora sem que o sentimento de pesar me dominasse.

Aos poucos sentia a mãe mais envolvida no exercício da maternagem, cumprindo as tarefas rotineiras (mamadas, manuseio nas trocas e banho) com espontaneidade e habilidade, mas ao mesmo tempo percebia certa falta de respeito ao ritmo e ao sono do bebê - acordava-o de sono profundo tirando-o do carrinho ou executando atividades domesticas sem o cuidado de poupar a filha dos ruídos que muitas vezes a tirava do estado de relaxamento, que Winnicott define como estado tranquilo, não integrado. 
A mãe veio da cozinha, olhou para mim e perguntou:

"Dormiu?" Olhou para o bebê e disse: "dormiu, vou trocar ela."

As duas pernas de S. estavam flexionadas e o braço esquerdo, semiflexionado.

A mãe havia saído da sala e voltou falando ao telefone, aproximou-se do carrinho falando alto e o bebê assustou-se. Ao desligar o celular retirou a filha do carrinho e colocou-a em pé no seu colo e me convidou para ir ao quarto acompanhar a troca de fralda.

Mãe: "Vamos trocar, princesa?" (Oitava Observação)

Era visível que S. queria continuar dormindo.

O barulho externo era intenso (carros, vozes,máquinas) e nada parecia perturbar o sono do bebê, a não ser o som vindo do interior da casa, como se algo tivesse caído no chão - Sara assustou-se, abriu os olhos fechando em seguida. A mãe passou pela sala e entrou no banheiro (cuja porta de acesso fica na sala, onde estávamos); logo ouvi barulho de torneira aberta e novamente o bebê assustou-se.

Os ruídos de dentro pareciam ser das atividades domésticas que a mãe estava executando - balde,vassoura, saco plástico - e Sara acordava, várias vezes, em sobressaltos.

... a mãe atravessou a sala com um balde nas mãos,nada silenciosa, o que fez com que Sara acordasse esfregando as mãos no rosto, mexendo as pernas e choramingando.

A mãe aproximou-se do carrinho, viu a filha tocando o rosto com as mãozinhas e disse: "acordou, o nariz tá trancado?" (Décima Quarta Observação)

Muitas vezes, a mãe sentia tanta necessidade de falar de si e eu ficava dividida entre as duas, mas o bebê parecia entender e sempre favorecia, acomodando-se no colo ou no carrinho, olhando-me, como se fôssemos cúmplices naquele momento.

O bebê ficou de frente para mim, meio sentado, meio deitado, de olhos bem abertos, quietinho enquanto a mãe falava comigo. (Décima Quarta Observação - bebê com três meses e catorze dias).

Em outras ocasiões Vanda me ignorou, esqueceu do nosso compromisso, fez questão de dizer que não me esperava, pediu que eu fosse ver o bebê onde ela estava, posicionou-se como se estivesse fazendo-me um grande favor. Sempre me contive e hoje penso que de algum modo, o seu comportamento fez parte de todo o sofrimento. Parecia que eu funcionava como o depósito de sua parte ruim, do seu ódio.

Entreguei o presente de Natal que levei para o bebê e uma caixa de panetone e outra de bombons para o casal. 
A mãe abriu primeiro o presente de $S$. demonstrando alegria, ao mesmo tempo dizia: "não precisava nada".

Colocou a roupinha na frente do bebê para verificar o tamanho e disse que se não servisse agora logo, logo serviria.

Ao abrir a caixa de chocolates ela olhou para a filha e disse: "a tia quer que a mamãe engorde"

Virou-se para mim e disse que ontem tinha ido aoCarrefour $e$ entre outras coisas tinha pegado uma caixa como aquela de bombons e que ao passar no caixa acabou deixando o pacote com a moça, alegando que estava gorda, mas agora, como ganhou iria ser obrigada a comer, em tom de brincadeira.

Quanto ao panetone, disse que quem iria gostar era o Edson : "ele adora, eu não gosto muito da massa, como mas não é aquela coisa”. (Vigésima Segunda Observação - bebê com cinco meses e nove dias).

A sensação transmitida por Vanda várias vezes ao me falar dos seus medos (de chuva, de ficar sozinha, de não conseguir dirigir após ter tirado carteira de habilitação, de não saber cozinhar) era equivalente a de um bebê desamparado.

Ao mesmo tempo, de forma ambivalente, escondia sua fragilidade demonstrando independência, competência através de reações de indiferença expressas por frases como "esqueci que você vinha", "desculpe, nem lembrei de você". Isso perdurou até a quinquagésima visita ${ }^{2}$.

O portão estava bem aberto quando eu cheguei e fui recebida pelo pai que me perguntou: "A Vanda não avisou você, ela tá trabalhando". (Vigésima Nona Observação). Cheguei às 18:30 e encontrei a casa escura e trancada. Voltei ao carro, estacionado do outro lado da rua e fiquei aguardando. Quinze minutos depois a mãe me ligou e perguntou se eu estava lá. Ela me disse que estava no Terminal, a caminho, que S. estava na casa da irmã e se eu poderia ir até lá. Concordei e com isso ela disse que iria tomar o ônibus para lá também. (Trigésima Oitava Observação- bebê com nove meses e vinte e cinco dias.

Cheguei às 16:50 conforme combinado e o portão estava trancado, com o cadeado do lado de fora.

Fiquei dentro do carro do outro lado da rua e às 17:15 a família chegou - o pai empurrando a carrinho e a mãe ao lado. Pararam conversar com a vizinha, sem demonstrar qualquer tipo de preocupação em relação a mim. Suspeitei que não estavam se lembrando de que era dia da observação e acertei.

\footnotetext{
${ }^{2}$ No dia 01/6/2010 não houve observação por não haver ninguém na casa. (Seria a Quadragésima Segunda Observação).
} 
Abriram o portão e estavam fechando quando atravessei a rua e chamei por Vanda. Ela olhou-me surpresa e disse algo que não pude entender completamente mas que significava que havia se esquecido. (Quadragésima Terceira Observação - bebê com onze meses e nove dias).

A ilusão de "maturidade" de Sara através de reações que pareciam se adaptar a mãe, era contraposta pelas somatizações (infecções repetidas), pela demora da dentição (até o último dia da minha visita o bebê não tinha nenhum dente), motivo de visível ansiedade da mãe, bem como pela falta de comunicação verbal, ela não falava nenhuma palavra até o nosso último encontro. Impressões descritas ao final do relatório da Quadragésima Quinta Sessão:

Tenho observado há algum tempo a preocupação da mãe com relação à dentição do bebê. Sempre que faz algum comentário comparando $S$. a outro bebê sinto que a mãe procura encontrar algo no desenvolvimento da filha que compense a "falta" de dentes. Outra observação é a vulnerabilidade do bebê em relação às infecções, no período de um ano ela já fez uso de antibiótico por várias vezes - não sei até que ponto é suscetível ou vítima de negligência. Certo dia pude observar a hora do banho e a banheira ficava junto à janela do quarto que estava aberta, num dia em que ventava. (bebê com um ano e quatro dias).

É possível que esses pontos correspondam a mecanismos defensivos contra o estado de angústia do bebê, de contenção da projeção dos sentimentos destrutivos. Pude presenciar um bebê mais tranquilo e espontâneo durante as observações na casa dos irmãos de Vanda, que continuaram morando na casa que era da mãe. Em função do falecimento desta, da cirurgia do marido, Sara ficou sob os cuidados da tia desde que a mãe voltou ao trabalho, após o período de licença-maternidade.

A tia-babá, como eu a nomeei nos relatórios, era muito jeitosa e carinhosa com a sobrinha e na casa havia sempre muita gente:

C. voltou ao quarto e sentou-se nos pés de S. e falava o quanto ela não dá trabalho, que dificilmente chora e que tem pena de saber que irá para a creche e não será mais carregada como é ali, com tanta gente rodeando, dando colo e atenção. Contou que ela já está começando a querer engatinhar, já tenta alcançar objetos distantes.

A.(a prima de treze anos) disse que vai sentir muita saudade do bebê.

C. disse que vai continuar cuidando da sobrinha por mais umas duas semanas, até V. encontrar a creche. (Trigésima Observação - bebê com sete meses e vinte e três dias). 
A primeira vez que fui realizar a observação na casa dos tios, cheguei com o pai e ao entrarmos na cozinha o bebê (cinco meses) estava no carrinho perto de duas tias. A voz alta de Edson assustou Sara que se virou em direção à porta e ao nos ver começou a chorar, principalmente quando me olhou - era um choro angustiado, profundo. $\mathrm{O}$ pai a carregou e demorou um tempinho para se acalmar.

Duas hipóteses podem ser levantadas: tive a impressão, ao chegar, que o bebê estava tão distraído, desconectado com o resto do mundo, em estado de descontração (nãointegração) e a voz do pai provocou uma espécie de pânico. Segunda hipótese: quem se apresentou ao lado do pai não foi a mãe e a minha presença pode ter salientado a ausência materna.

A última conjectura ficou praticamente comprovada no dia em que estávamos na sala dessa mesma casa, com alguns dos tios, primos, cunhados e Sara no meio de todos, brincando, exibindo gracinhas, mas distante de mim. Quando a mãe chegou do trabalho foi até lá onde estávamos e no instante em que percebeu a chegada da mãe, o bebê expressou intensa alegria e a partir daquele momento olhou para mim, sorriu e passou a se aproximar.

A mãe chegou e S., ao vê-la, esticou os bracinhos em sua direção. No colo da mãe jogou um beijo para mim.

Pai ligou e V.disse que ele havia pedido para eu dar uma carona a elas - mãe e filha.

Ao levantarmos para sair, do colo da mãe a bebê jogava beijos para a tia e para a prima, dava tchau, emitia sons, parecia querer falar.

Expressava alegria no colo da mãe, batia palmas, brincava com o fone de ouvido do celular enquanto mãe e tia conversavam antes de sairmos.(Trigésima Oitava Observação - bebê com nove meses e vinte e cinco dias).

Nossa comunicação sempre priorizou o olhar. O bebê da minha observação guiava e era guiado pelo olhar não só quando estava mamando e parava para encarar a mãe, como fixava os olhos em minha direção, com semblante sério. Durante toda a prática de observação havia essa busca, talvez como estímulo de aprendizado, talvez como busca de holding. Nos últimos contatos, a comunicação pré-verbal prevaleceu no jogo do olhar e da imitação de cenas do vídeo "Show dos Baixinhos" - Sara assistia calada e reproduzia ao seu modo, dançando, levantando os braços, batendo palmas, mas sem emitir sons. 


\subsection{ALGUMAS VINHETAS DAS OBSERVAÇÕES E COMENTÁRIOS}

Falta de sintonia e ansiedade da mãe em relação à volta ao trabalho:

O bebê dormia relaxado sobre o peito da mãe.

$V$. contou que vai voltar a trabalhar no fim de novembro e perguntoume como quero fazer, se vou continuar indo toda semana ou só nas folgas dela. Disse que quem irá cuidar do bebê será a irmã de 25 anos que foi demitida da empresa e como irá casar-se em maio, vai cuidar dos preparativos do casamento e de S. Caso eu continue indo semanalmente ela disse que poderá me explicar como chegar na casa da mãe, onde moram os irmãos.

Disse que pode ser que seja transferida para outra loja. Sugeriu que mude as observações para a noite, quando ela voltar do trabalho.

Mãe tira o bebê da posição relaxada que se encontrava, dormindo e colocou-a de pé. S. chorou ao ser acordada pela mãe. (Décima Terceira Observação - bebê com três meses e seis dias )

A impressão que tive ao relatar é que se instalou um estado de tensão à mãe, ao tratar a questão de sua volta ao trabalho e que aquela rotina seria interrompida - parece que ela atuou e acabou interrompendo o sono da filha.Nessa mesma observação será possível notar o desligamento natural da mãe que está deixando de dar atenção exclusiva ao seu bebê que está crescendo, buscando os próprios recursos para defender-se das intrusões do ambiente. Tudo vai acontecendo dentro das expectativas do processo de amadurecimento de Winnicott. Vejamos:

Disse que ainda está pensando se irá colocá-la na creche logo ou vai esperar até janeiro, se a irmã puder cuidar do bebê até lá.

Disse que o marido não daria conta de cuidar de $S$. o dia todo. O bebê mamava emitindo sons e se mexendo.

Mãe: "Ai, Sassá, assim dói". (Imaginei que o bebê tivesse mordido o mamilo da mãe).

O bebê soltou mais gazes, demonstrou desconforto, soltou o seio, movimentou-se, resmungou, voltou a sugar e logo soltou novamente.

Mãe deixou-a solta em seu colo enquanto guardava um seio e retirava o outro.

S. ficou resmungando e se mexendo, solta no colo da mãe e eu olhando, com preocupação e certa angústia. (Décima Segunda Observação-três meses) 
A preocupação e preparação da mãe para a volta da rotina profissional após o nascimento de S.; o bebê reagindo à negligência da mãe ao deixá-lo solto em seu colo, "brincando" enquanto mama e expondo sua instintividade agressiva sugando com mais força, ou talvez, mordendo o mamilo. A mãe falando de suas perdas no momento em que está prestes a separar-se da filha pela primeira vez:

O bebê olhava em minha direção, sorria, movimentava-se bastante, impulsionava o corpo para baixo até ficar com os pés para fora do carrinho. A mãe apareceu e a colocou de volta na posição anterior. Havia barulho de chuveiro e supus que fosse o pai, pois a mãe estava na sala mexendo em papéis. Em seguida aproximou-se da filha e disse: "Vamos tirar esse bori e colocar outro mais quentinho"? Sentou-se no outro sofá com o bebê no colo e tentou tirar a roupa de $S$. que manifestou sua rejeição através de resmungos, choramingo e movimentação corporal que impedia o ato da mãe. Esta me convidou $a$ ir até o quarto para tentar trocar a filha na cama.

Ao despi-lo, o bebê mexia-se bastante, olhava para a mãe com expressão de alegria e bem-estar, diferente da reação que apresentara há poucos instantes na sala.

Enquanto trocava novamente o bebê, $V$. contou-me que tinha ido à faculdade para mostrar a filha às amigas. Disse que no começo $S$. ficou assustada no meio de tanta gente, mas logo se acostumou. "Quem não ficou bem fui eu", disse V., senti saudade e um certo arrependimento de não ter voltado para terminar o curso com aminha turma". Disse que ficou uns dois dias mal e depois passou.

Disse que o nascimento de S. contribuiu menos do que a dor pela perda da mãe para voltar à faculdade, disse que não sentia vontade alguma de continuar naquele momento.

Pretendo concluir o curso quando $S$. estiver maior. (Décima quinta observação - bebê com três meses e vinte dias).

Após ter sido trocado, o bebê evacuou, provocando na mãe o mesmo procedimento que tinha acabado de realizar. (Parecia mesmo uma provocação do bebê, como se dissesse: "você não queria me trocar, agora tem serviço"). Mãe ocupada com outras atividades, bebê capaz de entreter-se com suas brincadeiras e explorações. Relacionamento tranquilo:

O bebê aceitou bem os medicamentos e depois ficou tranquila, aconchegada no colo da mãe, acordada.

Mãe colocou-a no carrinho, sentada, e disse-me que ia continuar o serviço doméstico. Foi para a cozinha. (Décima Nona Observação bebê com quatro meses e dezesseis dias). 
V. havia posicionado o carrinho do bebê de frente a mim, esta brincava com a chupeta, balbuciava, mexia pernas e braços, sorria para mim e dava impulsos para baixo até ficar com as pernas para fora do carrinho - eu a ajeitei algumas vezes, impedindo que caísse. Aqui pude experimentar a agradável sensação de ser espontânea, respondendo à atitude natural da mãe de confiar-me à filha. Ao sair do formalismo do Método, cuja regra é manter-se o mais neutro e passivo possível, pude interagir com o bebê e percebê-lo capaz de distrair-se na ausência da mãe.

Punha e tirava a chupeta da boca, depois colocava as mãos, os dedos, emitia sons, gritinhos e sorria quando olhava em minha direção parecia conversar comigo.

Colocou o indicador direito na boca - "ahahahahah", como se tivesse descobrindo os sons que era capaz de produzir.

Mexia-se bastante, suas expressões faciais eram compatíveis à sensação de prazer, de satisfação, sempre me olhando, sorrindo, soltando gritinhos.

Às vezes começava a choramingar, mas logo voltava a se entreter com seus sons e movimentos, a chupeta também a acalmava. (Décima nona Observação - bebê com 4 meses e 16 dias).

$\mathrm{Na}$ vigésima segunda observação pude presenciar momentos de intensa sintonia e alegria entre a dupla. O ambiente era de descontração, harmonia, espontaneidade e comunicação num clima de muita afetuosidade. Pude observar e sentir que Sara não estava faminta mas usava o seio para manter o contato com a mãe, chamar a atenção para si, pois soltava o mamilo, olhava para a mãe, buscando um encontro, a resposta do sorriso que vinha com uma palavra carinhosa, com um olhar seguido de um sorriso, enfim, um meio de comunicação que envolvia só a dupla.

Foi interessante observar que a amamentação não estava saciando outra necessidade que não a de buscar o contato da mãe. Brincadeiras, vivacidade, boa comunicação (Vigésima Terceira Observação - bebê com cinco meses e vinte e nove dias):

Pai saiu da sala e fiquei atenta aos movimentos do bebê, que de fato movimentava-se bastante, dava impulsos com o corpo, levantava a cabeça. Manuseava o chocalho com uma ou com as duas mãos, olhava em minha direção, às vezes sorria.

O pai saiu e a mãe veio à sala e sentou-se ao lado da filha, que demonstrou muita alegria ao ver a mãe - ria alto, mexia pernas e braços, olhava fixamente para o rosto de V.. Esta correspondeu com carinho, beijos, levantou a filha e aproximou-a do seu corpo. O bebê mordia o rosto da mãe e dava gargalhadas, emitia sons como se tivesse entoando uma melodia. 
A mãe colocou-a de volta à cama e disse: "fica aí brincando pra tia ver que a mãe vai comer um pãozinho". Pegou outros brinquedos $e$ colocou ao redor da filha, que pegava um, depois outro e assim ficou tempo se distraindo com os objetos, brincando.

Contou que a irmã cuida muito bem de S. e que só vai colocá-la na creche quando estiver maior.

A mãe colocou o bebê de volta na cama e ofereceu-lhe novamente os brinquedos. Mãe contou-me que nos dias de sua folga S. só quer ficar com ela, raramente aceita ir até com outra pessoa, inclusive com o pai. Contou, também, que ela já sabe procurar o seio à noite. Disse: "nós estamos dormindo juntas e às vezes, sinto ela procurando o seio, não sabe ainda puxar a blusa, mas já sabe pedir." Olhou para a filha e disse: “eu tô muito esperta, tia”.

A mãe levantou-se e disse que ia preparar os legumes para a papinha dela, pediu licença e foi à cozinha. O bebê começou a resmungar, a gritar, como se tivesse chamando a atenção da mãe, principalmente quando ela ouvia a voz ou via a mãe à distância. Ao perceber, a mãe aparecia, brincava com a filha e saía novamente.

Brincava mais um pouco e voltava a reclamar; a mãe conversava com ela da cozinha e eu comecei a me incomodar com o incômodo do bebê. A mãe veio, sentou-se no sofá, carregou S., deixou-a em pé e ofereceu-lhe o seio direito. Disse-me: "agora ela mama de pé”. Матои muito poисо e soltou; continuou inquieta. Mãe guardou o seio.

Deixou a filha na cama e foi à cozinha novamente. O bebê manifestou-se com grande movimentação do corpo e choro. Sentei-me ao seu lado na cama, tentava se levantar até que acabei carregandoa, sentei no sofá e coloquei-a sentada nas minhas pernas. Ela ficou brincando com meu relógio, meu cinto e ficou quieta.

Ao perceber que eu havia carregado o bebê, a mãe falou: "tava querendo colo, né".

Logo a mãe veio para a sala e pegou a filha. Disse que ao invés de dar banho ia deixar ela dormir um pouco; deitou-a e ofereceu o seio esquerdo.

Percebi que o bebê está se desenvolvendo normalmente, já sabe manifestar seus interesses e necessidades de modo que seja compreendida. Já está sabendo brincar com os objetos ao seu redor (chupeta, brinquedos, mãos, pés, outros).

Demonstrou tranquilidade, ótima interação com a mãe, capacidade de estar só em grande parte do tempo, o que sugere relação de confiança entre mãe e bebê. ( $25^{\text {a }}$ observação 6 meses e seis dias). A capacidade de estar só é descrita por Winnicott como uma conquista da fase de dependência absoluta onde a provisão do ambiente inaugura a experiência de 
previsibilidade e confiabilidade, conforme descrito anteriormente. Trata-se da experiência de poder estar só, mesmo na presença da mãe.

\section{Sara pronta para o desmame:}

A mãe carregou-a e sentou-se novamente no sofá. Ofereceu-lhe o seio esquerdo, disse: "acho que ela tá com sono, acordou oito horas".

S. mamava um pouco e soltava o mamilo, inquietava-se, a mãe ajeitava-a novamente ao seio e assim fez algumas tentativas até que a mãe mudou para o outro seio, mas o bebê não mamou quase nada.

A mãe ajeitou o sutiã, baixou a blusa e ficou tentando encontrar uma posição para acalmar a agitação da filha que não conseguia acomodar-se de modo algum.

Parecia estar com sono, pois esfregava os olhos, sugava a chupeta com força, encostava a cabeça no corpo da mãe, em seguida levantava, tentava alcançar algum objeto ao redor (chocalho, celular da mãe) ou mesmo a chupeta, tirava e tentava colocar de volta e não conseguia encaixar do lado certo, irritando-se.

A mãe comentou que a bebê não estava mais querendo mamar, estava achando que seu leite já está acabando pelo fato de estar trabalhando e ficar fora o dia todo. (Vigésima sétima Observação - bebê com sete meses e três dias).

A mãe demonstrava carência de atenção e S. mantinha-se entretida com suas brincadeiras enquanto V. falava de questões pessoais. Essa experiência era conhecida por nós três, desde o princípio, quando a mãe precisava de um tempo dela, Sara parecia compartilhar antes silenciando e agora, em pleno desenvolvimento brincando:

Mãe colocou o bebê na água e havia aberto a janela bem atrás da banheira - achei que estava ventando, mas não falei nada; durante o banho ela fechou uma parte e várias vezes o bebê espirrou.

A mãe falava muito comigo, parecia que estava carente da minha presença para conversar, contar coisas dela.

O bebê mostrava-se bem, cooperando com a mãe, brincava com as mãos batendo na água, olhava pra mim, sempre séria, às vezes emitia sons como se estivesse cantando, enquanto a mãe falava e eu ouvia.

O banho até demorou mais tempo do que o habitual; senti que a mãe estava esticando o tempo para poder ficar sozinha comigo, para poder conversar. (Trigésima Primeira Observação - bebê com oito meses) 


\section{Exploração do ambiente, uso e controle de objetos:}

A mãe me disse que a mama estava cheia e que precisava esgotar um pouco, estava com uma toalha nas mãos secando o leite excedente. O bebê começou a sugar o seio esquerdo deitada sobre o braço da mãe e logo seus olhos foram se fechando. Mãe disse que a filha estava com sono.

Contou que o bebê ainda estava gripado e que tinha levado-a ao pediatra. "Ela tá com nove $\mathrm{Kg}$ ", contou a mãe com expressão de satisfação.

O bebê mamava e soltava o mamilo, mais brincava do que mamava. A mãe escondeu o seio e colocou a filha sentada sobre suas pernas. Mexia-se muito, tentava alcançar objetos ao seu redor, como o controle remoto da $\mathrm{TV}$, minha bolsa e quando conseguiu segurar a alça da minha sacola de tecido a mãe lhe disse: "é da titia, titia vai brigar". (Trigésima Terceira Observação - bebê com oito meses e catorze dias).

Percebi S. bastante agitada (sentava, levantava, movimentava pernas, braços, cabeça, puxava a blusa da mãe, buscando o mamilo, sugava, arranhava o seio, a mãe reclamava de dor, tocava o corpo da mãe (seio) brincando como costuma brincar com seus brinquedos exploração do objeto, controle do objeto, poder sobre o objeto.

\section{Harmonia em família:}

Chegaram juntos pai, mãe e filha às 19:03.

Pediram desculpas, a mãe disse que havia acabado de descer do onibus e os encontrou. S. estava no colo da mãe, sorridente.

Ambas sentaram-se ao meu lado no sofá e S. jogou-me um beijo, alcançou o controle remoto da TV que estava perto e começou a brincar. Repetia diversas vezes "mamamamamama".

A mãe dizia: "Chame a mamãe". Falou, pausadamente, olhando para a filha: "mamãe".

O bebê continuava emitindo o mesmo fonema enquanto brincava.

Sugeriu ao bebê tomar um banho, levantou-se e disse que ia preparar a água. Colocou a panela com água para esquentar e convidou-me para irmos ao quarto; carregou $S$ e lá, colocou-a no berço.

$O$ pai entrou no quarto no momento em que a mãe tirava a roupa do bebê. Ele disse: "vai tomar banho, gorda?

O pai permaneceu no quarto passando roupa para ir trabalhar enquanto a mãe dava banho no bebê, que demonstrava alegria, batia palmas, jogava beijos. 
O pai contou-me que chegava às 6hs da manhã do trabalho, dormia até as 8:45, levava a filha à creche, voltava e dormia até as 11 hs para começar a cuidar das marmitas. (Quadragésima Observação - bebê com dez meses e nove dias).

Impressões: a nova rotina da família parece ter sido adaptada para atender às necessidades do casal em relação à filha. Como qualquer mudança exige tempo para adaptação, percebi que os três estão inseridos nesse contexto. Porém, observei a família reunida como há algum tempo não acontecia. Refiro-me à interação entre eles e eu, a presença do pai no mesmo ambiente da observação. Chamou-me a atenção a alegria do bebê no momento do banho, quando estávamos todos reunidos no quarto.

O bebê permanecia no carrinho, alegre, os pais conversavam entre si e comigo e o assunto principal era o aniversário de $S$. que está chegando.

A mãe, sentada no sofá, disse que tem ajudado a irmã na confecção de marmitas e que quando $S$. está em casa tem que ficar de olho nela, porque está muito "levada" - mexe em tudo.

Colocou a filha no chão para que eu a visse ficar de pé e dar um passinho. (Quadragésima Terceira Observação - bebê com onze meses e nove dias)

\section{O descompasso da dupla:}

V. contou que sábado e domingo teve que trabalhar e o bebê ficou com a tia e o pai, respectivamente.

Parou de falar e prestava atenção à novela enquanto alimentava a filha.

O bebê movimentava o corpo como se estivesse dançando. Ela gritou e a mãe disse: "não grite, o papai tá dormindo".

No colo da mãe, tenta alcançar o controle remoto e a mãe não deixou, deu um brinquedo a ela. Soltou o brinquedo e tentou mais uma vez pegar o controle da TV. O bonequinho havia caído no chão e a mãe não percebeu, estava concentrada na televisão.

S. não parava de se movimentar do colo da mãe ao sofá; sentou de frente à mãe em seu colo, batia no peito desta, puxava-lhe pela camiseta, balbuciava. (parecia estar pedindo atenção).

Mãe disse que não tinha tido tempo de fazer nada na casa. Disse: "o carrinho da S. fica na creche, ela não fica no berço, quer colo e no chão não dá pra deixar, o hack pode cair em cima dela e às 11hs da noite, depois que ela dorme, eu não tenho pique pra fazer mais nada". 
O bebê se movimentava, virava, deitava de bruços, sentava de frente à mãe, puxava sua blusa, punha a chupeta na boca, tirava.

Ao deitar de costas no colo da mãe, esta começou a fazer cócegas na barriga do bebê que dava gargalhadas. (Quadragésima primeira Observação - bebê com dez meses e dezesseis dias)

A mãe posicionou-a sentada de frente para a TV e ao olhar para mim, que estava sentada ao seu lado esquerdo, deu tchau sorrindo. Retribui o gesto.

Virou-se no colo da mãe, colocou e tirou a chupeta. A mãe perguntoulhe: "Tá com sono, venha aqui, encosta aqui para dormir um pouco". Disse a mim que desde que chegou da creche a filha estava querendo dormir. Levantou-se com $S$. no colo e foi ao banheiro lavar a chupeta que havia caído no chão.

Ao sentarem-se, V. mudou o canal da TV para outro que exibia o desenho do pica-pau, incentivando a filha a assistir.

O bebê não parecia interessado, batia palmas, dava tchau, movimentava o corpo, emitia sons -e-e-e-e-e...

Mãe atendeu ao celular e ao desligar fez uma ligação. Enquanto conversava $S$. não parava em seu colo, expressava agitação pulando, brincando com o controle remoto, "falando". Colocou o polegar na boca e tirou.

A mãe ajeitou o aparelho celular entre o ombro e o rosto para conter S. que demonstrava inquietação enquanto a mãe falava ao telefone em tom irritadiço (parecia que algo não tinha saído da maneira como desejava - sobre o casamento da irmã que ocorreria no sábado daquela semana).

Depois de tanto se mexer, o bebê deitou a cabeça no colo da mãe com as pernas no sofá e $V$. começou a passar a mão na cabeça da filha, ainda falando ao telefone. Segundos depois o bebê iniciou novamente sua agitação. "Pára, S., você vai apanhar, heim".

Ao desligar, a mãe perguntou: "porque você tá assim"? , demonstrando impaciência.

S. sentou-se de frente à mãe e esta disse: "Mamãe brigou, não mamãe não brigou, mas por que você tá chata, não pode ficar chata assim, tem que dormir."

O bebê choramingou e a mãe disse: "papai tá dormindo para ir trabalhar, mamãe já falou”.

Senti que o desencontro com o horário do marido pode estar sendo motivo de insatisfação à Vanda

S. esfregou os olhos, deitou no ombro da mãe e logo levantou.

$V$. olhou pra mim e disse: "Olha como luta contra o sono."

O bebê recostou-se de novo no peito da mãe que a beijava, a acariciava, a ninava como há meses atrás, quando a filha era bebezinho. S. aquietou-se. 
Mãe disse que vai comprar DVDs para a filha assistir e também outro carrinho para deixar na casa. Beijava a filha com carinho.

S. virou o rosto para o meu lado, como se quisesse se certificar se eu continuava ali.

V. cobriu a filha com uma fralda; o bebê fechou os olhos e a mãe continuava a beijar a face de $S$.

Ao me despedir, o bebê dormia aconchegado ao colo da mãe. (Quadragésima primeira Observação - bebê com dez meses e dezesseis dias)

Impressões: senti a mãe estressada, desamparada, sem poder atender às demandas de atenção da filha, fazendo papel de guardiã do sono do marido, mas no fim recuperando-se e sendo capaz de voltar-se ao bebê e dar-lhe continência, até que S. pudesse relaxar e dormir.

\subsection{ASPECTOS SOBRESSALENTES}

Desde o início das observações alguns fatos chamavam à atenção da observadora, tais como: quadros repetidos de gripes e resfriados do bebê, a televisão sempre ligada, o pai na maioria das vezes ausente, mesmo estando em casa, necessidade da mãe em demonstrar o crescimento do seu bebê e sua competência como mãe; quem cuidaria do bebê quando retornasse ao trabalho. Vejamos alguns fragmentos de observações que ilustram as ocorrências acima:

\section{Estado vulnerável de saúde:}

"Você acredita que ela pegou um resfriadinho? Tá com tosse, percebi que tinha secreção e segunda levamos ela ao pediatra - tá tomando remédios, um pra tosse e outro pra descongestionar." (Primeira Observação - bebê com catorze dias).

"S. está tossindo, tá gripada, disse a mãe. O médico prescreveu esses medicamentos..." (Trigésima segunda Observação - bebê com oito meses e onze dias)

Mãe, com a filha no colo me contava que S. estava tomando remédio de novo (antibiótico). "Levei ela ao médico e tá com o peito cheio de 
catarro." (Trigésima sexta Observação - bebê com nove meses e oito dias).

Contava-me que a bebê tinha ficado dez dias sem ir à creche por ter ficado gripada - "teve que tomar antibiótico, não teve jeito", disse a mãe. (Quadragésima segunda Observação - bebê com dez meses e vinte e nove dias)

Minutos antes de eu ir embora a mãe me contou que S. tinha ficado doente no fim de semana. Disse: "Quinta, na hora que você saiu ela tava tossindo,lembra? Então, aquela noite ela acordou umas sete vezes, não conseguia dormir e quando foi de manhã resolvi levar ela ao médico. Teve que tomar antibiótico, precisa ver quanta secreção ela soltou pelo cocô.O médico disse que ela tá com um pouco de anemia, acho que é porque ela não tava gostando muito da papinha, agora ela tem comido bem, tô dando feijão, ferro todo dia pra ela ficar fortinha, né bebê?" (Vigésima Observação - bebê com quatro meses e vinte e quatro dias)

Impressões: havia a impressão de falta de cuidado materno em relação a condições climáticas características do inverno; havia também o momento de fragilidade emocional devido às circunstâncias - a mãe estava exercendo a maternagem em processo de elaboração do luto pela perda da mãe dela. Mais tarde, já frequentando a creche, era previsível a suscetibilidade às infecções, devido ao contato com outras crianças.

\section{Falta de apoio paterno}

O pai apareceu na sala e a mãe pediu para ele colocar um pouco de chá na colher e deu à filha. Depois pediu ao marido que comprasse o medicamento recomendado pelo médico porque já deveria ter começado a tomar. Ele respondeu que não sabia se teria tempo para ir à farmácia. (Quinta observação - bebê com quarenta e um dias).

Por várias vezes senti o pai ausente mesmo presente; passava pela filha, brincava rapidamente com ela e saía. Como será que ele se sentia com a aquela situação, ele também poderia estar carente. Certas atitudes do marido podem ter contribuído para que ela manifestasse preocupação na volta ao trabalho:

A mãe relatou a preocupação com relação à volta ao trabalho que deverá ocorrer no início de dezembro; não sabe ainda com quem deixará a filha à noite, acredita que E. (o marido), como qualquer 
homem, não é capaz de cuidar direito de um bebê. (Terceira Observação - bebê com vinte e oito dias).

\section{Superação e competência}

Enquanto manipula a filha, que está desperta e se movimentando, ela contou que levou o bebê ao pediatra do posto e que S. havia engordado e crescido - 5,600Kg e $57 \mathrm{~cm}$. Expressou orgulho e satisfação ao falar do desenvolvimento da filha. O pai também expressou o mesmo tipo de sentimento ao dizer: "fico bobo de ver os pernões dela." (Nona Observação - bebê com sessenta e nove dias).

A mãe contou, orgulhosa, que a filha está com 7,500Kg e $65 \mathrm{~cm}$, o que segundo o médico, revela que o bebê está se desenvolvendo bem. (Vigésima segunda Observação - bebê com cinco meses e nove dias)

... a mãe comentou que havia levado-a ao pediatra e que ela estava pesando 8,280Kg; falou com satisfação sobre a robustez da filha. (Trigésima Primeira Observação - bebê com oito meses).

Impressões: entendia como parte da elaboração do luto da mãe o fato de ela poder constatar e compartilhar seu sentimento de que estava contribuindo com o crescimento e o desenvolvimento da filha. Sentia a necessidade de comparar o seu com outros bebês da mesma idade e o grau de insatisfação e preocupação quando Sara não apresentava os sinais esperados e desejados para determinada fase.

A mãe disse a ela: "você não vai ficar em pé pra tia ver? Ela já levanta sozinha do chão e fica uns segundos parada, sem segurar." Falou isso demonstrando satisfação, mas ao mesmo tempo disse que tinha ido no aniversário de uma menininha de um ano que já tinha dentes e não andava ainda. Percebi, mais uma vez, a preocupação quanto à dentição de S., que ainda não se manifestou. (Quadragésima Quinta Observação - bebê com um ano e quatro dias).

\section{Desligamento do emprego da mãe:}

Contou sobre o desligamento do emprego - que estava muito insatisfeita e que o gerente queria que ela mudasse de horário, que fosse para o período noturno. "Como eu ia se o E. trabalha à noite? 
Daí eu conversei com o E. e achamos melhor eu sair e eles concordaram em me mandar embora".

O bebê brincava, sorria, balbuciava, não parava quieta, ia do colo ao sofá, voltava; a mãe disse que ela estava querendo andar. Disse à filha: "conte pra tia - eu não tenho dente mas já quero andar".

"Ela já fica um tempinho parada e tenta dar uns passinhos".

$V$. disse que ia colocá-la no carrinho para preparar a papinha.

Ao ser colocado no carrinho o bebê não hesitou; a mãe posicionou-o de modo que ficasse de frente a mim e de costas para a TV. (Quadragésima segunda observação - bebê com dez meses e vinte e nove dias).

Achei interessante a preocupação da mãe em propiciar a interação entre o bebê e eu. No passado não era um procedimento comum. Conforme o tempo foi passando, de estranha virei "tia".

A mãe disse: "Fique aqui com a tia pra mamãe fazer sua papinha".

Deu à filha um mordedor em forma de mão, vazado no meio.

S. começou a brincar com o objeto fazendo-o aparecer e desaparecer e cada vez que o derrubava ficava me olhando e olhando o mordedor como se estivesse esperando eu apanhá-lo para dar continuidade à brincadeira.

Aqui podemos perceber aspectos importantes como a elaboração da separação através das brincadeiras de esconde-esconde e da confiança da mãe em dividir a filha comigo.

Desde o momento em que entrei no jogo, ela ria muito e alto chamando a atenção da mãe, que da cozinha fazia comentários do tipo: "nossa que alegria Sasá, tá gostando de brincar com a tia".

Foram comentários demonstrativos de satisfação pela interação entre observadora e bebê.

Depois de uns bons minutos a mãe voltou a sala com a papinha e ao ver o prato imediatamente ignorou o mordedor e começou a choramingar e levantou os braços para que a mãe a retirasse do carrinho.

A mãe começou a alimentá-la ali mesmo no carrinho. O bebê comia com vontade, abrindo a boca a cada colherada, demonstrando prazer no que estava consumindo. Balbuciava, mexia-se, colocava a perna para fora do carrinho e assim foi até consumir toda a porção.

Ao acabar a mãe carregou-a e logo S. começou a dar sinais de que estava com sono.

Quando o tempo de observação acabou ela estava recostada no colo da mãe, quase dormindo. (Quadragésima segunda observação - bebê com dez meses e vinte e nove dias).

Impressões: a mãe parecia mais tranquila, talvez por ter saído do emprego. Percebi certa preocupação com relação à dentição do bebê que ainda não começou. 


\section{Momentos finais do período das cinquenta observações}

Percebi certa nostalgia por parte deles, lembrando a vinda da filha ao mundo, antes da data prevista, V. lembrou-se da dor da perda da mãe, o quanto que ela ainda estava abalada emocionalmente.

O bebê estava no chão, engatinhando embora a mãe quisesse muito que ela desse uns passinhos para me mostrar. Isto acabou acontecendo depois, quando o pai voltou e enquanto eles falavam comigo, S. ficava em pé e dava uns passos até o pai, que estava em pé perto da porta da frente ou em minha direção, no sofá. Ficava em pé por uns segundos no meio da sala e seguia cambaleando ou então se sentava no chão.

$V$. contou que o presente de aniversário que ela mais gostou foi o que eu havia dado e um carrinho que ela entra e anda, mas ainda não sabe direito.

A mãe disse: "eu pergunto pra ela cadê a Joaninha e ela já sabe o que é; às vezes eu desligo o botão para não gastar a bateria, mas ela já sabe ligar”.

O pai disse que era verdade, que não era por estarem na minha frente.

A mãe foi buscar o carrinho para eu ver, a Joaninha já estava ali.

Senti, naquele instante, sentimento de gratidão deles por mim.

Percebi que S. tentava entrar no automóvel, mas ainda é alto para ela subir sozinha. Ao ser colocada no assento ela impulsionou o carrinho com os pés e rapidamente chegou na porta da sala.

A mãe disse: "Viu Ed como tá essa menina, precisa tomar cuidado, tá muito esperta, não pode descuidar um segundo”.

A mãe trouxe-a para perto de si e $S$. quis descer. Novamente tentava subir e assim procedia - engatinhava, ficava em pé, andava apoiando-se no sofá, voltava ao carrinho sob os olhares de todos. (Quadragésima Sétima Observação - bebê com um ano e um mês)

Acabou meu horário e me despedi com a sensação de que S. estava se desenvolvendo bem e que o clima familiar era favorável e estimulante.

\section{Quadragésima Nona Observação: clima de despedida}

A TV estava ligada e o bebê olhava fixamente para o programa ao qual assistia - Show da Xuxa.

$V$. contou que S. estava adorando esse vídeo, que ficava quietinha assistindo e ela podia fazer todo o serviço. 
Parecia que a mãe queria o silêncio do bebê ou usava a TV como "babá" para envolver-se em outras atividades domésticas.

Contou que no aparecimento de alguns personagens que gosta mais costuma dançar e imitar a coreografia que fazem, como o cachorro, o urso. Pude notar o que a mãe me contara no decorrer da observação - às vezes o bebê levantava os braços, movimentava o corpo como se estivesse dançando e batia palmas; não sorria, não emitia sons, continuava séria.

Chamou-me a atenção o silêncio do bebê durante vinte minutos da observação, aproximadamente.

Enquanto permanecia atenta à TV a mãe ia me relatando os últimos acontecimentos...

Depois contou que ia começar a fazer aulas de direção com pessoa especializada em casos como o dela - insegurança para dirigir. Disse que não podia mais ficar dependendo do marido, precisava começar a sair sozinha.

No momento em que a mãe dá sinais de independência a filha reforça com os sinais dos dentinhos.

Contou que dois dentinhos estavam dando sinal de vida e que o médico havia dito que assim que surgisse o primeiro logo viriam os outros.

O show acabou e V. mudou para a novela, disse que era a última semana e ela queria assistir.

S. continuou calada apenas fez um gesto com a mão direita simbolizando "acabou" (palma da mão virada para cima).

A mãe reiniciou o show e o bebê manifestou satisfação através da movimentação com o corpo e palmas.

A mãe levantou-se e colocou S. em meu colo, disse que ia fazer café.

$O$ bebê acomodou-se sentada sobre minhas pernas e em silêncio continuou olhando para a TV.

S. estendeu os braços em direção à mãe que estava no sofá ao lado e a partir daí começou a se soltar - foi ao chão, aproximou-se da TV e ficou em pé assistindo bem de perto e às vezes dançava, batia palmas. O bebê ia até a cozinha e voltava, já não estava mais tão atenta ao show.

A mãe sugeriu que fôssemos trocar a fralda no quarto. Fomos e ao colocar S. na cama de casal esta começou a andar de um lado a outro, caia, se jogava, caminhava em minha direção, perto da janela, ria, não parecia a mesma criança de minutos atrás. 
A mãe contou que na creche $S$. gosta muito do parquinho e que a professora havia dito que ela é a criança mais feliz da escola.

Senti que para a mãe essa declaração valeu como um certificado de competência por sua maternagem.

Impressões: senti que o clima era de despedida, que cada um, pai, mãe e bebê expressava, de algum modo, os sentimentos de pesar pela nossa separação que estava prestes a acontecer; a próxima seria a última da cinquenta visitas de observação da relação mãe-bebê na residência daquela família.

Uma das hipóteses levantadas no decorrer das observações pode ser confirmada na décima quinta observação e no decorrer dos encontros realizados. Não demorou muito para que a observadora percebesse que a falta de apoio materno tinha sido mais severa e impactante para Vanda do que a perda concreta da mãe.

Enquanto trocava novamente o bebê, $V$. contou-me que tinha ido à faculdade para mostrar a filha às amigas. Disse que no começo $S$. ficou assustada no meio de tanta gente, mas logo se acostumou. V. disse: "Quem não ficou bem fui eu, senti saudade e certo arrependimento de não ter voltado para terminar o curso com a minha turma". Disse que ficou uns dois dias mal e depois passou.

Disse-me a mãe que o nascimento de $S$. contribuiu menos do que a dor pela perda da mãe para voltar à faculdade, disse que não sentia vontade alguma de continuar naquele momento e que só iria concluir o curso quando Sara estivesse maior.(Décima Quinta Observação bebê com três meses e vinte dias).

Reafirmou isto na visita pós-observação.

$\mathrm{O}$ aspecto Ambiente (grifo meu) destacado como objetivo desta pesquisa demonstrou sua importância para o estabelecimento das bases para o amadurecimento saudável de Sara.

\subsection{A ÚLTIMA OBSERVAÇÃO (BEBÊ COM UM ANO, DOIS MESES E VINTE E SEIS} DIAS)

O portão estava fechado com cadeado, a casa escura, apenas a luminosidade em movimento da TV ligada sugeria que havia alguém na sala. 
A mãe disse: "ela tá dormindo, mas já acorda". Sentou-se ao lado da filha e começou a mexer com ela, falar, sem preocupar-se com o sono dela.

O bebê dormia de bruços e com os estímulos da mãe ela acordou e virou-se. V. disse a filha: "olha quem tá aqui, a tia E."

Talvez por ser a última observação a mãe estivesse preocupada com o aproveitamento do tempo.

S. ainda sonolenta sentou-se, olhou em minha direção, séria e assim permaneceu durante bom tempo.

S. começou a ficar mais desperta depois de uns vinte minutos da observação. A mãe colocou-a no chão e ela aproximou-se de mim, que estava sentada no sofá ao lado. Ela chegou bem perto, encostouse na minha perna esquerda e movimentou-se de maneira a ficar em pé entre minhas pernas apoiada com os dois cotovelos um em cada coxa, de frente à televisão. Sempre calada.

A mãe pediu para o bebê mostrar-me os dois dentes e ela mostrou-me a língua. A mãe disse: "a língua não, o dentinho". $V$. segurou a cabeça de $S$. e inclinou-a de modo que eu visualizasse os dentes que ainda nem despontaram.

Ela mesma percebeu sua ansiedade em relação à dentição da filha ao dizer para mim: “só a mãe mesmo que enxerga, nem dá pra ver ainda. Eu esbocei um sorriso. Era ansiedade ou necessidade em auto-valorizar-se como se dissesse "só eu na qualidade de mãe posso enxergar o que ninguém pode."

Havia um clima de certa ansiedade que a mãe tentou ocultar, foi a reprodução de muitas outras situações semelhantes quando a ouvi dizer que tinha se esquecido que eu iria naquele dia e que seria o último.

Enquanto a mãe falava comigo o bebê estava atento a nós, em silêncio, olhando às vezes para a TV.

A mãe perguntou a filha se ela queria ver o show e imediatamente passou para o vídeo sem aguardar a resposta.

$V$. falava sem parar, demonstrando muita ansiedade.

Parecia tomar todo o espaço da observação chamando a minha atenção a ela.

S. assistia ao show da Xuxa sem a concentração habitual, parecia sensivel ao estado ansioso da mãe, que falava, falava, beijava a filha, acariciava os cabelos dela, perguntou se eu tinha visto que ela tinha cortado o cabelo da filha. S. começou a ficar mais desperta depois de 
uns vinte minutos da observação. A mãe colocou-a no chão e ela aproximou-se de mim, que estava sentada no sofá ao lado. Ela chegou bem perto, encostou-se na minha perna esquerda e movimentou-se de maneira a ficar em pé entre minhas pernas apoiada com os dois cotovelos um em cada coxa, de frente à televisão. Sempre calada.

A mãe continuava falando sem parar e pedindo a filha que fizesse as demonstrações das últimas aquisições do seu repertório, como dizer "não" com o dedinho. Contou-me que outro dia deixou o bebê de castigo sentado no sofá e que ela ficou quietinha, enquanto S. assistia novela sentada no outro sofá. Contou também que o pai lhe deu um tapinha na mão porque $S$. reagiu de forma agressiva ("ficou nervosa e quis bater no pai", disse a mãe) "Ela já sabe o que é não, o que não pode; tenho dó mas não pode deixar, senão ela não vai aprender".

O bebê saiu de perto de mim e se aproximou do móvel em frente onde fica a TV; abria e fechava a porta de um compartimento pequeno, em baixo da televisão provocando um barulho alto em meio ao silêncio do ambiente, pois falávamos baixinho e S. estava bem quieta até então.

A mãe dizia: "S., não pode fazer barulho,vai acordar o papai".

Ela repetiu algumas vezes e em todas $V$. chamou a atenção da filha.

Tive a impressão de que Sara provocou uma situação naquele exato momento para ilustrar o que a mãe estava me dizendo.

S. voltou a ficar perto de mim, de costas para a TV, parecia não mais interessada no show; queria mexer na minha bolsa e a mãe dizia: "não pode mexer nas coisas da tia, ela vai ficar brava com você". A mãe pegou a boneca que eu havia levado de presente a ela e disse: "olha a sua boneca, que nome você vai dar pra ela?"

Ao se aproximar do final do horário daquela última visita ambas apresentavam-se mais agitadas e assim como na primeira observação em que Vanda ocupou o tempo falando esta seguiu a mesma característica e enquanto a mãe falava, Sara corria, dançava, subia, engatinhava como nunca havia feito.

Uma das últimas coisas que a mãe me disse foi: "agora eu estou me sentindo mais segura para dirigir sozinha" - referindo-se ao carro, mas possivelmente, em relação à nossa separação também, com o final das visitas de observação.

A mãe levantou-se e foi à cozinha buscar água para mim.

Ao voltar contou que tinha feito algumas aulas de direção e que se sentia mais segura para dirigir, mas que ia precisar vencer logo essa barreira senão, voltaria ao estado de insegurança. 
Contou-me que havia conversado com uma pessoa na faculdade sobre o seu retorno ano que vem para concluir o semestre que ficou faltando para se formar.

Enquanto isso S. andava de um lado a outro, subia e descia do sofá, abria o armário, parava em frente a TV, dançava, demonstrava energia e bom humor.

Minha hora havia chegado ao fim e senti que V. continuava falando, não queria saber do limite imposto pelo tempo do relógio e do programa de observação.

Como na primeira visita o bebê estava resfriado, como na primeira o pai estava ausente e como na primeira, pouco antes de eu sair, mãe e filha se juntaram - Vanda posicionou seu bebê de um ano e quase três meses deitado em seus braços e disse: "agora vamos dormir, bebê?"

Nesse momento o bebê estava no colo da mãe, demonstrando sono. A mãe aconchegou Sara em seu peito, como costumava fazer bem no começo; a pequena criança encostou a cabeça e fechou os olhos embalada pelos movimentos cadenciados e tranquilizantes da mãe

Nossa troca de olhares havia se esgotado. Despedi-me da pequena Sara com um beijo suave em sua testa.

\subsection{SENTIMENTO DE GRATIDÃO}

A quadragésima sétima observação revela o sentimento de gratidão dos pais em relação ao trabalho desenvolvido silenciosamente através do período intenso de observações. O pai expressou em nome dele e da mãe (que referendou suas palavras) dizendo que se sentiam privilegiados e apoiados mesmo que eu ficasse apenas olhando.

A mim, que fui acolhida e respeitada por eles, para por em prática meus estudos, sentime profundamente grata e cúmplice da parte fundamental do processo de amadurecimento da pequena Sara, que se refere ao princípio do surgimento de um ser único que partiu da unidade básica mãe-bebê. 


\subsection{FRAGMENTOS DA VISITA APÓS O PERÍODO DAS OBSERVAÇÕES SEGUNDO O MÉTODO ESTHER BICK - SARA COM A IDADE DE DOIS ANOS E NOVE MESES}

Segundo acordo entre os pais (Edson e Vanda) e Maria Estela, a autora desta Pesquisa de Dissertação de Mestrado, nos encontramos no dia 07/4/2012, sábado às 9h na residência da família, que continua instalada no mesmo endereço e cidade.

Cheguei dez minutos antes do horário e estacionei o carro em frente a um salão que abriga uma igreja, do outro lado da rua, defronte à casa. Pensei em aguardar ali até as 9h, mas percebi que o pai já tinha me visto chegar e me deu sinal para me aproximar.

Recebeu-me com um afetuoso abraço e se antecipou a contar, antes que entrássemos, que estavam muito tristes porque haviam recebido a notícia de que um amigo íntimo, de 28 anos, havia falecido logo cedo vítima de câncer, descoberto em dezembro. Disse que Vanda estava chorando desde que receberam a ligação de alguém que estava no hospital no momento do falecimento. Soube, depois, ao longo do nosso contato que o moço foi noivo da tia-babá, tinham convivido durante sete anos em família e que a amizade permaneceu mesmo com o rompimento do noivado.

A mãe estava me aguardando na sala com expressão de imensa tristeza e lágrimas nos olhos. Abracei-a numa mistura de solidariedade e saudade. Não pude deixar de relacionar esta à situação inicial das observações, quando logo na primeira visita fui surpreendida pelo triste acontecimento envolvendo a morte da mãe de Vanda.

O bebê que virou uma menininha linda, agora com dois anos e nove meses, encantoume com o mesmo olhar curioso e vivo. Aproximou-se e estendeu os bracinhos para me abraçar estimulada pelos pais que me inseriram como uma figura familiar desde que ela nasceu. Logo o ambiente se caracterizou como parte de integrante de nossa história. Andava e falava com desenvoltura e o tempo todo em que permaneci com eles, senti um clima de muita harmonia, alegria e amadurecimento de todos.

Pai e mãe mudaram de emprego - ela trabalha na indústria em que ele trabalhava no período em que as observações ocorreram e Edson tinha trocado totalmente de ramo visando trabalhar em horário administrativo visando conviver mais com a família, foi enfático ao me dizer isto. Comentou que antes não tinha a mesma visão e responsabilidade, que hoje a família é prioridade para ele, acompanhar o crescimento de S. está sendo a coisa mais importante 
junto com o nível de diálogo que mantém com Vanda. Foi assertivo ao dizer que no início da vida em comum, que coincide com o nascimento da filha, mal se falavam.

Entendi que tudo o que pude observar e às vezes, questionar, em relação ao não envolvimento dele com a família, quando não apoiava a esposa, não dava atenção à filha, definia a imaturidade, a falta de prontidão para assumir responsabilidades daquela natureza. Confessou-me que foi muito difícil ter perdido a sogra como ponto de apoio, mas só agora é que tem noção do que realmente aconteceu e que Vanda foi muito forte para vencer e cuidar da filha. Contou que ficou bem da cirurgia do joelho, já voltou a jogar futebol, mas que agora, logo que acaba o jogo toma uma "cervejinha" com o pessoal e volta pra casa.

Esse encontro seguiu uma linha tão informal que ora eu estava conversando só com o pai, ora estava só com Sara (dois anos e nove meses) ou com Vanda e de repente, nos deparávamos os quatro no mesmo ambiente, como na cozinha, por exemplo, onde ficamos juntos, os três sentados ao redor da mesa redonda e eu em pé, conversando, gravando e filmando, sob consentimento deles. Tomando café com eles, entre eles, pudemos ouvir Sara nos contar histórias, que segundo os pais ela adora inventar, ouvir e contar.

Contando a história da bruxa (que ela pronuncia "buta"), foi auxiliada pela mãe para se fazer entender, pois embora a mãe entenda o que a filha fala, parece saber que a comunicação não é clara nem mesmo ao pai. No meio da história ela disse que a bruxa pegou a menininha e a mãe interferiu dizendo que o pai havia salvo a menina (Vanda me contou que ela muda e mistura as histórias); Sara concordou com a mãe e seguiu dizendo: “eu não posso sair na rua porque senão o carro pega eu e a mamãe fica sem menininha”.

O que senti aqui, é que a mãe cortou a espontaneidade, a expressão criativa da filha e fez com que ela passasse à realidade.

A menina continuou falando incentivada pelos pais. O pai disse à filha: "e o que não pode fazer pra mamãe?" Ela fez gesto de bater.

Sara disse em tom mais alto: "sai daqui, tamém não pode, né?"

S. "Vou contar 'outa' história agora: tinha vez um chapeuzinho...(fez uma pausa e disse: vou contar do chapeuzinho amarelo; depois eu vou contar do lobo mal e do chapeuzinho vermelho, tá?"

Mãe: Tá.

S.: Tinha uma vez um "tapeutinho" amarelo, daí o lobo mal apareceu pra pegar o “tapeutinho" vermelho. Daí o "tapeutinho" correu do lobo mal bem forte, correu. Daí a "buta" pegou o lobo mal. 
Pai: "Não pode pegar o chapeuzinho vermelho".

S.: "Não pode".

Pai: "Chapeuzinho vermelho é boazinha".

S. repetiu o que o pai havia dito. Daí o lobo foi embora (com ênfase) e nunca mais pegou o chapeuzinho vermelho, chapeuzinho amarelo, nunca mais, nunca mais.

Os pais perguntam: "E daí?"

S. "E daí? Daí acabou.

Todos nós batemos palmas.

Depois contou uma história da mãe que bateu no menininho que mostrava a língua e a mãe disse: "Daí ele não mostrou mais a língua, não pode né, igual a Sara". E ela concordou dizendo: "É."

Após o café, enquanto conversava com o pai, a mãe estava no banho, Sara foi para o seu quarto, onde havia um colchão de casal no chão e lá reuniu todas as suas bonecas e ficou brincando, colocou-as para "dormir" e deitou-se ao lado. Edson (pai) e eu ficamos conversando na porta de entrada do quarto enquanto observávamos o entretenimento de Sara com suas bonecas.

Essa cena trouxe-me duas impressões: a primeira relembrava o início das observações quando o bebê se silenciava como se estivesse identificada às necessidades da mãe e segundo, ali, naquela situação, simulou um ambiente de silêncio, colocando as bonecas para dormir, permitindo que pai e observadora conversassem. A segunda, a demonstração de que é uma criança de quase três anos e que está agindo como tal e portanto, condizente ao estágio previsto no processo de amadurecimento.

A confiança estabelecida no ambiente primário aponta para a capacidade de estar só mesmo com a mãe presente e pude observar Sara brincando em seu quarto com suas bonecas enquanto os pais encontravam-se por perto ou em outros aposentos da casa. "A brincadeira fornece uma organização para a iniciação de relações emocionais e assim propicia o desenvolvimento de contatos sociais.” (Winnicott, 1985, p. 163).

O tempo todo fiquei com a sensação de que Sara buscava manifestar-se espontaneamente, livremente, deixando emergir seu si-mesmo verdadeiro, distanciando-se dos primórdios da vida quando parecia adequar-se ao ambiente, calando-se como se colocasse como holding da mãe em momentos de ansiedade e angústia de Vanda.

Pude sentir que sua adequação ao ambiente parece funcionar oportunamente, algo comum no indivíduo saudável em situações onde a flexibilidade é importante. Com o passar 
do tempo, durante o acompanhamento desta família, seremos capazes de verificar esta e outras questões, como a linguagem, e intervir favoravelmente. Ficou estabelecido que os encontros no domicílio da família ocorrerá no mínimo uma vez ao ano.

Em duas horas e meia que se passaram rápido e agradavelmente, pude constatar que as tarefas do amadurecimento estão seguindo um padrão adequado na vida daquela menina, salvo, a não precisão de palavras na expressão oral. Percebi que Sara tem dificuldades para pronunciar algumas palavras (troca do $\mathrm{C}$ pelo $\mathrm{T}$ em algumas palavras). Não considerei aquele o melhor momento para uma intervenção, mas pretendo orientar os pais a procurarem um fonoaudiólogo para avaliação. Sara continua na mesma creche e gosta muito de brincar com os coleguinhas na escola e com suas bonecas em casa.

Vanda me confessou que voltará à faculdade no próximo semestre para concluir o curso de Recursos Humanos e num outro momento relembrou o difícil início, desde que recebeu a notícia da morte da mãe e apesar da dor apegou-se à lembrança da força materna que sua mãe sempre lhe transmitiu e que foi isso que a manteve forte em relação à experiência da maternagem. Disse: "minha mãe jamais me perdoaria se eu ficasse sofrendo e não cuidasse da minha filha". Continuou: "foi mais por isso, pela perda da minha mãe, que eu não voltei para a faculdade, meu emocional não estava bom; agora sim, eu vou voltar".

Nada como a alegria e a vivacidade de uma criança para dar vida à morte. 


\section{CONSIDERAÇÕES FINAIS}

Houve um "desastre" no final da gestação dessa jovem mulher, ao perder de forma inesperada a própria mãe que lhe serviria de suporte no momento e após o parto. Uma vida surgiu, antecipadamente, desviando a atenção da morte.

O que pudemos observar desde o início das observações desta relação é que amor e dor se revezavam através de expressões de ansiedade, angústia, silêncio, negligência, medo, agressividade, fragilidade, alegria, vitalidade, compreensão, cuidado, preocupação.

O bebê antecipou sua chegada trazendo vida ao espaço da perda deixado pela avó, mas pode ter causado na mãe intensa angústia de morte verificada pelo excesso de medicamentos ministrados ao longo do primeiro ano de vida, além de várias vezes ter acordado a filha para alimentá-la e ainda, pelas comparações em relação ao desenvolvimento do seu bebê e os outros.

Apesar de ter perdido seu principal apoio, Vanda realizou a função materna com dedicação, seguida de emoções adequadas, às vezes um pouco escassas, outras desencontradas ou em excesso.

As limitações do marido (internas e concretas) como um elemento de apoio, levaramna a contar com o suporte das irmãs no cuidado com o bebê e da observadora, ocasionalmente, para suas projeções e desabafos. Em vários momentos, também pude perceber a necessidade que a jovem mãe tinha de projetar seu ódio no ambiente (observadora), ao "esquecer-se" do horário e dia da observação - várias vezes fiquei esperando por ela em frente à casa. Outras vezes, demonstrando insatisfação com a minha presença, evidenciando um pequeno atraso de minha parte, ou fazendo questão de desvalorizar alguns presentes que a observadora ofertou, ocasionalmente.

Isto faz parte da confiança estabelecida numa relação espontânea e confiável, onde o ambiente (neste caso a observadora) permanece o mesmo diante dos ataques, continuando sempre presente.

A dentição prorrogada, remete-nos à hipótese da contenção inconsciente do bebê de conter sua agressividade; embora frágil, Sara parece ter acionado, precocemente, recursos mentais para adaptar-se ao ambiente. E se isto aconteceu, haverá possibilidade de se verificar posteriormente, ao longo do seu desenvolvimento se houve submissão ao ambiente e consequentemente, fuga do self verdadeiro. No momento atual não há indícios de que a 
dentição seja motivo de preocupação dos pais. "O gesto espontâneo é o Self verdadeiro em ação; somente o self verdadeiro pode ser criativo e sentir-se real.” (Winnicott, 2000, p. 135).

O mutismo do bebê, a não reação em forma de protesto às intrusões ambientais, em diversos momentos captados pela observadora, puderam ser compensados com expressões de muita vivacidade, alegria, mobilidade, especialmente quando o ambiente apresentava-se harmonioso e receptivo.

"São as inúmeras falhas, seguidas pelo tipo de cuidados que as corrigem, que acaba por constituir a comunicação do amor, assentada sobre o fato de haver ali um ser humano que se preocupa." (WINNICOTT, 1999, p. 87)

"Um fato importante a considerar é que, graças a uma assistência satisfatória, estes sentimentos terríveis se transformam em experiências positivas, vindo a somar-se à confiança que o bebê adquire com relação ao mundo e às pessoas." (WINNICOTT, 1999, p. 76).

Em relação ao bebê, uma das coisas mais surpreendentes nessa experiência foi perceber a grandeza de um ser tão incipiente - foi comovente perceber nos rudimentos de uma personalidade que surgia, a existência de um bebê tão valente. Sara soube chegar ao mundo e acalentar a mãe com seu silêncio oportuno quando ela precisava chorar sua dor, soube conter sua dentição para não feri-la, resmungar como sinal de vida, dormir em seus braços tranquilamente numa demonstração de confiança.

Assim como Winnicott descreveu a mãe suficientemente boa, ouso mencionar aqui um "bebê suficientemente bom" como resultado de uma maternagem que funcionou como ambiente primário adequado, humano e portanto, falível, mas sem qualquer sombra de dúvidas, atento, adequado e facilitador ao caminho do amadurecimento de Sara.

"No caso da maior parte dos bebês, o fato de serem desejados e amados pelas mães, pais e demais membros da família fornece-lhes o contexto no qual cada criança tem a oportunidade de se tornar um indivíduo, não apenas realizando seu destino seguindo a trajetória do legado hereditário (na medida em que a realidade exterior o permita), mas também feliz por ser capaz de identificar-se com as outras pessoas, animais e coisas do meio ambiente, bem como com a sociedade e sua perpétua auto-organização." (WINNICOTT, 1999, p. 77).

Tudo isso só é possível porque a dependência, que inicialmente é absoluta, passa à relativa e caminha para a independência (autonomia), gradativamente, é reconhecida e há um adulto, preferencialmente a mãe, ou quem quer que cumpra a função materna. O maior 
aprendizado que o bebê Sara me deixou foi que palavras podem ser ditas, suprimidas, mal elaboradas, mas jamais expressarão o que se ouve pelo olhar dos sentidos.

\subsection{UMA HISTÓRIA SEM FIM}

Voltar a ver Sara com seus dois anos e nove meses foi uma grata e feliz surpresa.

Encontrei um lar harmonioso, o casal mais unido, comprometidos com a educação da filha, mas naquele dia, muito abatidos e tristes.

Ficamos juntos por duas horas e quinze minutos numa rica experiência de reencontros e redescobertas que puderam ser registradas não só pela troca de olhares, emoções, palavras, como pude registrar a maior parte dos momentos, filmando e gravando, sob consentimento dos pais.

Esta história terá continuidade através do acompanhamento do desenvolvimento da criança cuja proposta de observação e intervenção, se necessário, prevê ao menos uma visita a cada ano, conforme acordo entre os pais e a pesquisadora.

Combinamos que por meio de comunicação virtual ou por telefone poderemos manter contato para qualquer eventualidade, necessidade e orientação. Enfim, o ambiente de holding ficou estabelecido nesta família como prevenção e intervenção de saúde e desenvolvimento individual e familiar.

\subsection{A CHANCE DE UM BOM COMEÇO}

Os registros das experiências infantis, embora armazenados em algum lugar, não são tão simples de reconstituição, mas as emoções, os sentimentos aliados às experiências podem vir à tona em forma de sintomas, como medo e sofrimento.

É aqui a chance de se retornar (regredir), através da análise pessoal (psicoterapia) às etapas iniciais do amadurecimento onde o vínculo mãe-filho tem o poder de facilitar ou perturbar o processo de crescimento. Com o analista (psicoterapeuta) como ambiente de holding, numa relação mútua de previsibilidade (presença viva e constante do profissional) e 
confiabilidade (mediante um setting que segue o mesmo padrão repetidamente), o indivíduo poderá retomar o ciclo do seu desenvolvimento.

Em termos de prevenção, podemos pensar na instalação de programas de saúde que visem à preparação de médicos, enfermeiros, que apesar de especialistas em suas funções, muitas vezes, desconhecem a base para a experiência humana de exercer a maternagem. A mãe não precisa de técnica, mas de apoio para tornar-se, espontaneamente, o melhor ambiente para que o potencial de ser de seu bebê constitua-se em si-mesmo (self).

\subsection{PALAVRAS FINAIS}

Assim como iniciei esta dissertação de forma pessoal, encerro também, com um toque humano e pessoal.

Em 1990, havia ingressado no Programa de Mestrado em Psicologia Clínica da Pontifícia Universidade Católica de São Paulo e logo no início das aulas fiquei sabendo que estava grávida. Dois projetos, duas gestações.

Tomada pelo sentimento materno de dedicação e envolvimento exclusivo, tranquei matrícula na PUC e mergulhei fundo na preparação de um ambiente capaz de fazer com que aquele coração que pulsava em meu útero se transformasse em possibilidade de se tornar um ser único e saudável.

Vinte e um anos depois, o antigo projeto, adormecido, ressurgiu, foi gestado e recebeu a mesma devoção para se tornar tão único e importante como um verdadeiro filho. Em ambas as situações a confiança e a previsibilidade do ambiente foram essenciais para o bom desenvolvimento. 


\section{CONCLUSÃO}

Ao centralizar minha atenção ao título desta Dissertação concluo afirmando que a sensação de ter tido uma experiência suficientemente boa como bebê e criança foi determinante para que Vanda encontrasse no amor a força de exercer, naquele momento de dor, a maternagem.

As falhas ocorridas foram brevemente corrigidas evitando um padrão repetido e traumático capaz de instalar um quadro psicótico, que segundo D. W. Winnicott se configura nos estágios de dependência absoluta e de dependência relativa do processo de amadurecimento, que compõem os primeiros quatro meses de vida.

A presença viva do pai, a demonstração de estar consciente da sua importância no meio familiar deixou claro que seu apoio mantém a mãe capaz de sentir-se confiante e feliz consigo mesma e no exercício da maternagem e a criança, ao sentir que as relações entre os pais proporcionam um lar harmonioso, cresce com facilidade e segurança, mesmo que as intrusões do ambiente externo se interponham, inevitavelmente, no curso natural do desenvolvimento.

Outro aspecto que nos aproxima da visão de um desenvolvimento integrado e não cindido é poder constatar que Sara mantém a ilusão de onipotência (criatividade originária) como se tivesse, de fato, criado o mundo ao recontar histórias infantis do seu próprio jeito (Self verdadeiro). Não percebi a prevalência de reações defensivas ao ambiente - finalidade do falso si-mesmo. Winnicott (1997, p. 148), assinala que o falso self pode adequar-se ao padrão familiar, a certa perturbação da mãe e ser tomado como sinal de saúde, mas não deixa de sinalizar instabilidade.

Ao longo da vida somos, eventualmente, "convidados" (grifo meu) a proteger nosso self verdadeiro (nossa espontaneidade e criatividade) para atendermos a demandas do ambiente. Uma das expressões conhecidas e muito utilizadas no momento que ilustram o que estou dizendo é "politicamente correto", quando situações, comentários, ações, desviam-se do impulso primário criativo para proteger o indivíduo de possíveis retaliações e incompatibilidade do viver em sociedade.

Em continuidade, na mesma página (148), ao tratar do tema "Saúde como maturidade emocional", Winnicott diz: "o adulto maduro é capaz de identificar-se com seu ambiente e tomar parte do estabelecimento, na manutenção e na alteração desse ambiente sem sacrificar 
seriamente seus impulsos pessoais". A importância do acompanhamento deste caso permitirá avaliar os sinais de um crescimento com base na saúde e aqueles que poderão constituir as enfermidades. 


\section{REFERÊNCIAS}

ABRAM, J. A Linguagem de Winnicott. Rio de Janeiro: Revinter, 2000.

AMARAL, L. A. Observação de Criança - Relação Mãe-Bebê. São Paulo: Jornal de Psicanálise, v. 36(66/67), p.285-293, 2003.

BADINTER, E. Um Amor Conquistado - o mito do amor materno. Rio de Janeiro: Nova Fronteira, 1980.

BATISTA PINTO, E. A Pesquisa Qualitativa em Psicologia Clínica. São Paulo: Psicologia USP, São Paulo, v. 15(1/2), p.71-80, 2004.

BICK, E. Notas sobre Observação de Bebês no Ensino de Psicanálise. The Internacional Journal of Psychoanalysis, v. XIV, 4, 1964.

BITTENCOURT, A. M. L . Tangências de Winnicott em Freud. São Paulo: Jornal de Psicanálise, v. 37, p. 68, 2004.

CUNHA, I. Bebê com manual de instruções. Estratégias de comunicação mãe-bebê. Jornal Mente Corpo, Porto Alegre, Ano IX, nº 82, p. 14, dezembro, 2011.

DIAS. E.D. A Teoria do Amadurecimento de D. W. Winnicott. Rio de Janeiro: Imago, 2003.

FARIA, M.T.B.F. A Bela e a Fera. São Paulo: Jornal de Psicanálise, v. 25(48), p.95-110, 1992.

FREUD, S. Obras Completas: Luto e Melancolia. Vol. XIV. Rio de Janeiro: Imago, 1974. Três Ensaios sobre a Sexualidade. Vol.VII . Rio de Janeiro, 1974.

HERMANN, F. Pesquisa Psicanalítica. Ciência e Cultura. Vol. 56, no 4. Oct./Dec. 2004

HOUZEL, D. Infant Observation and the Receptive Mind. Infant Observation, London, Vol. 13, no 2, August 2010, p. 119-133, 2010.

KHAN, M.M.R. Psicanálise: teoria, Técnica e Casos Clínicos. Rio de Janeiro: Francisco Alves, 1984.

KIGNEL,R. O Corpo no Limite da Comunicação. São Paulo: Summus Editorial, 2005.

KORBICHER, C. F.; FONTES, M.H.S. (1992). A Observação de Bebês e sua relação com os Estados Mentais Primitivos. Jornal de Psicanálise, São Paulo, v. 25(48), p.111-127, 1992.

LAPLANCHE, J.; PONTALIS, J.B. Vocabulário de Psicanálise. Neutralidade. Rio de Janeiro: Martins Fontes, 1970. 
LEVINZON, G.K. Vicissitudes da Neutralidade no Processo Analítico. Jornal de Psicanálise, São Paulo, v. 31(57), p. 137-147, 1998.

LISONDO, A.B.D. El despertar de La vida mental em el encuentro com el mundo externo. Método Esther Bick - observaciones y teorias. VIII Congresso Internacional de Observação de Lactentes, 2008.

LOWENKRON, A.M. Pesquisa Clínica na Psicanálise: caminhos. Jornal de Psicanálise, São Paulo, Vol. 39, nº71, 2006

LITTLE, M.P. Ansiedades Psicóticas e Prevenção. Rio de Janeiro: Imago, 1992.

McLAIN, P. Casados com Paris. Rio de Janeiro: Nova Fronteira, 2011.

MÉLEGA, M.P. Observação da Relação Mãe-Bebê - Instrumento de Ensino em Psicanálise. Revista Brasileira de Psicanálise de São Paulo, São Paulo, Vol.21, p.309, 1987.

MELTZER, D. Identificação Adesiva. Jornal de Psicanálise, São Paulo, Vol. 19, n³8, 1986.

MONMAYRANT, M.; LACROIX, M. B. (org.). A Observação de Bebês: os laços do encantamento. Porto Alegre: Artes Médicas, 1997.

PAPALIA, D.E.; OLDS, S. W. O Mundo da Criança. São Paulo: McGraw-Hill, 1981

PÉREZ-SANCHES, M. Avaliação Psiquiátrica do Bebê. Espanha: Association Bick España - Boletim no 2 - setembro/2005.

PRAT, R. O Diálogo das Emoções. Jornal de Psicanálise, São Paulo, v. 25(48), p.129-158, 1992.

SANTOS, Maria Estela E.A. Gestação e Prevenção- Enfoque Psicanalítico. São Paulo: aula no Curso de Graduação em Enfermagem Das Ciências Médicas da Santa Casa - disciplina “Aspectos Multiprofisssionais na Prevenção ao Uso de Drogas”, 2008.

. Entre a Dor e o Amor. Sorocaba: Relatório Final do Curso Observação da

Relação Mãe-bebê na Família - Associação Pró-Reintegração da Criança,

2010.

SAURET, M-J. A Pesquisa Clínica em Psicanálise. Psicologia USP, São Paulo, v. 14(3), 89104, 2003.

TURATO, E.R. Introdução à Metodologia da Pesquisa Clínico-Qualitativa - definição e Principais Características. Porto, Portugal: Revista Portuguesa de Psicossomática, jan-jun, ano/vol.2, número 001, p. 93-108, 2000.

UNIMARCO EDITORA. Observação da Relação Mãe-Bebê: Método Esther Bick. Tendências. Coletânea de Artigos: $1^{\circ}$ Simpósio Brasileiro de Observação da Relação MãeBebê. São Paulo, 1997. 
WINNICOTT, D.W. Tudo Começa em Casa. São Paulo: Martins Fontes, 1986.

. A Criança e o seu Mundo. São Paulo: Zahar,1965.

. Os Bebês e suas Mães.São Paulo: Martins Fontes, 1999.

. Da Pediatria à Psicanálise. São Paulo: Imago, 2000.

Fontes, 1997.

A Família e o Desenvolvimento Emocional. São Paulo: Martins

. Pensando sobre Crianças. São Paulo: Artmed, 2005.

. A Natureza Humana. Rio de Janeiro: Imago, 1990.

. O Ambiente e os Processos de Maturação.Porto Alegre, 1983.

. O Brincar e a Realidade. Rio de Janeiro: Imago, 1975.

WINNICOTT, C.; SHEPHERD, R; DAVIS, M. (Org.). Explorações Psicanalíticas:

D.W.Winnicott. Porto Alegre: Artmed, 1994. 


\section{ANEXO 1 - COMITÊ DE ÉTICA}

\section{(20000 \\ UNIVERSIDADE PAULISTA}

Vice-Reitoria de Pós-Graduação e Pesquisa

\section{CERTIFICA D O}

CERTIFICAMOS, que o protocolo $n^{\circ} 562 / 11$ CEP/ICS/UNIP, sobre o projeto de pesquisa intitulado "Efeitos do luto materno na relação mãe-bebê", sob a responsabilidade, MARIA ESTELA ESCANHOELA AMARAL SANTOS, está de acordo com os Princípios Éticos, seguindo diretrizes e normas regulamentadoras de pesquisa envolvendo seres humanos, conforme a Resolução n $n^{\circ}$ 196/96 do Conselho Nacional de Saúde e foi aprovado por este Comitê de Ética em Pesquisa.

Universidade Paulista, em São Paulo-SP, aos 13 dias do mês de outubro de 2011.

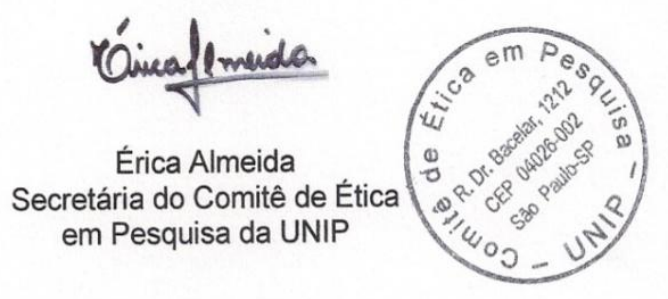

